NBER WORKING PAPER SERIES

\title{
CENTRAL BANK TRANSPARENCY: CAUSES, CONSEQUENCES AND UPDATES
}

\author{
Nergiz Dincer \\ Barry Eichengreen \\ Working Paper 14791 \\ http://www.nber.org/papers/w14791
NATIONAL BUREAU OF ECONOMIC RESEARCH
1050 Massachusetts Avenue
Cambridge, MA 02138
March 2009

State Planning Organization, Ankara, and University of California, Berkeley, respectively. An earlier version of this paper was presented to the conference on Money Matters: The Law, Politics and Economics of Currency, held at Tel Aviv University on 7-9 January 2009. We are grateful to Tal Sadeh and other conference participants for helpful comments. The views expressed herein are those of the authors and do not necessarily reflect the views of the National Bureau of Economic Research.

NBER working papers are circulated for discussion and comment purposes. They have not been peerreviewed or been subject to the review by the NBER Board of Directors that accompanies official NBER publications.

(C) 2009 by Nergiz Dincer and Barry Eichengreen. All rights reserved. Short sections of text, not to exceed two paragraphs, may be quoted without explicit permission provided that full credit, including (c) notice, is given to the source. 
Central Bank Transparency: Causes, Consequences and Updates

Nergiz Dincer and Barry Eichengreen

NBER Working Paper No. 14791

March 2009

JEL No. E0,E58

\begin{abstract}
$\underline{\text { ABSTRACT }}$
We present updated estimates of central bank for 100 countries up through 2006 and use them to analyze both the determinants and consequences of monetary policy transparency in an integrated econometric framework. We establish that there has been significant movement in the direction of greater central bank transparency in recent years. Transparent monetary policy arrangements are more likely in countries with strong and stable political institutions. They are more likely in democracies, with their culture of transparency. Using these political determinants as instruments for transparency, we show that more transparency monetary policy operating procedures is associated with less inflation variability though not also with less inflation persistence.
\end{abstract}

Nergiz Dincer

State Planning Organization

Ankara

Turkey

nergiz.dincer@gmail.com

Barry Eichengreen

Department of Economics

University of California, Berkeley

549 Evans Hall 3880

Berkeley, CA 94720-3880

and NBER

eichengr@econ.Berkeley.edu 


\section{Central Bank Transparency: Causes, Consequences and Updates ${ }^{1}$ Nergiz Dincer and Barry Eichengreen February 2009}

\section{Introduction}

Commenting on British monetary policy in 1929, Otto Niemeyer, director of financial inquiries at H.M. Treasury, observed that "In prewar days a change in bank rate was no more regarded as the business of the Treasury than the colour which the Bank painted its front door."2 In 1987 William Greider entitled his expose of the Federal Reserve Secrets of the Temple. ${ }^{3}$ Since then the world of monetary policy has changed. Transparency now is a byword. Central banks are supposed to be open about their objectives, outlooks, policy strategies, and even their mistakes. The days when monetary policy deliberations were regarded as no more the business of outsiders than the color than the central bank chose to paint its door are now firmly in the past.

Or so it might seem. Assessing whether this move in the direction of policy transparency is permanent - and if so how far it might go - or whether it might be reversed requires understanding what lies behind the trend in the first place. One view is that transparency enhances the effectiveness of monetary policy. Transparency about monetary policy objectives, outlooks and strategies is necessary for effective communication with the markets, and effective communication is necessary for monetary

\footnotetext{
${ }^{1}$ State Planning Organization, Ankara, and University of California, Berkeley, respectively. An earlier version of this paper was presented to the conference on Money Matters: The Law, Politics and Economics of Currency, held at Tel Aviv University on 7-9 January 2009. We are grateful to Tal Sadeh and other conference participants for helpful comments.

${ }^{2}$ Cited in Eichengreen, Watson and Grossman (1985).

${ }^{3}$ See Greider (1987).
} 
policy to have stabilizing effects. Policy transparency makes it easier for observers to anticipate central bank actions and minimizes disruptions when policies change. It enhances the ability of policy makers to manage expectations, which is a key channel through which monetary policy affects outcomes. Transparency about not just current but also expected future policy gives the central bank leverage over long-term interest rates (which depend on expectations) and thus provides an important mechanism for influencing consumption and investment.

The seminal research on this subject built on the Barro-Gordon (1983) model in which wages are set now on the basis of expected future monetary policy. ${ }^{4}$ Imagine, for example, that inflationary pressures are building and unions contemplate raising their wage demands. If the central bank is transparent about the priority it attaches to price stability, the risk it perceives that inflation will exceed its target, and the likelihood of having to respond by raising interest rates, then wage setters will have reason to anticipate that inflationary pressures will subside. They will be less likely to demand higher wages now that would, require costly and difficult wage reductions in the future. The disruptions to the economy from policies to contain inflation would be less. And monetary policy makers are less likely to fall prey to an expectations trap in which expectations drift off in ways that force them into unpalatable policy choices. ${ }^{5}$

Transparency thus allows the central bank to more effectively communicate with the markets. It helps it to credibly commit. It is a way for monetary policy makers to communicate the importance they attach to price stability. ${ }^{6}$ This in turn enables them to

\footnotetext{
${ }^{4}$ See for example Geraats $(2002 \mathrm{a}, \mathrm{b})$.

${ }^{5}$ See Clarida, Gali and Gertler (2000) and Christiano and Gust (2000).

${ }^{6}$ Faust and Svensson (2001) consider a model in which the public attempts to infer whether or not the central bank is serious about limiting inflation from information on policy outcomes. Its inferences are
} 
respond flexibly to disturbances without undermining confidence in their commitment to their long-term target.

A second view is that transparency is a mechanism for democratic accountability in a world of policy discretion and central bank independence. Once upon a time central bank policy was constrained by rules like those of the gold standard, if not absolutely then at least more tightly than today. Central banks may have had statutory independence - many of them were in fact still private banks - but they did not have policy independence. ${ }^{7}$ The demise of the gold standard was associated with the spread of modern central banking but also with increasing central bank dependence on the government (as alluded to in Niemeyer's quote above). At this stage there was no question about the political accountability of the central bank. More recently has there been recognition of the efficiency advantages of delegating the conduct of monetary policy to an independent entity. Moreover, with the move away from pegged exchange rates, central banks have acquired greater discretion over the stance of policy. But with the growth of independent powers comes a need for democratic accountability, for assurance that the independent technocrats now with discretion over monetary policy

imperfect because of unanticipated policy-implementation errors that the public is incompletely able to observe. Greater transparency about economic conditions thus enables agents to infer the central bank's preferences more accurately. In turn this gives the monetary authority an incentive to build a reputation for valuing price stability. The private sector becomes more sensitive to unanticipated policy responses and actions, attenuating the incentive for the central bank to engage in them. The result is thus greater sensitivity of inflation expectations to policy actions, the less benefit to the central bank of inflating, and less inflationary bias. In this way increased transparency about control errors improves social welfare. Greater transparency about the central bank's objectives may be more of a mixed blessing in this framework. Transparency about objectives, in addition to reducing uncertainty about future inflation and output, which will be welfare improving other things equal, removes the central bank's incentive to curtail inflation in order to signal its type, which can be welfare reducing.

${ }^{7}$ Moreover, the influence of monetary policy over economic and financial conditions, while never something about which observers were exactly ignorant, was less fully appreciated than today, when traders hold their breath on the days when the central bank announces its interest-rate decision. And where the extent of the franchise and of political contestability were limited, there was no more need for the central bank to be democratically accountable than any other branch of government. 
decisions take those decisions in a manner consistent with the public interest and will be taken to task for failing to do so. This mechanism for democratic accountability will be effective only if the central bank is transparent about its decisions - only if those deciding monetary policy cannot claim that their policy decisions are, in fact, in the public interest for reasons that only they understand. In the absence of adequate transparency, suspicion about central bank motives may develop, and pressures to curb the institution's independence may be irresistible.

Both rationales have been questioned. If asymmetric information is a distortion, then the theory of the second best suggests that removing one distortion in the presence of another may not be welfare improving. It is not hard to construct scenarios in which additional transparency destabilizes expectations and accentuates financial market volatility. ${ }^{8}$ Similarly, there are critics of the view that transparency can substitute adequately for direct political sanctions as a mechanism for holding monetary policy makers accountable. ${ }^{9}$

In addition, even those who embrace these efficiency- and accountability-based arguments wonder whether central bank transparency can go too far. The European Central Bank has justified its refusal to publish the minutes and voting records of its board on the grounds that individual members would then be subject to pressure from

\footnotetext{
${ }^{8}$ Morris and Shin $(2002,2005)$ illustrate the point in a model in which individual welfare depends not just on the state of the world but on the actions of other individuals (there exists a coordination externality). Starting from a position where both private and public information are imperfect, they show that greater precision of public information can lead individuals to attach inadequate weight to private information. In the absence of coordination motives, the precision attached to the public and private signals will be commensurate with their relative precision. When coordination motives are present, however, agents attach greater weight to the public signal, since they know this to be common information. But since the public signal is noisy, this weight on the public signal may be suboptimal from a social-welfare point of view; agents may be led to coordinate on an inefficient equilibrium. This adverse outcome is more likely the more precise is private information.

${ }^{9}$ Thus, some critics of the European Central Bank, whose transnational status, embedded in an international treaty, makes it difficult for national politicians to sanction those responsible for its policy, question whether policy transparency provides adequate political accountability.
} 
special interests (national interests, in its context) that compromised their independence and led to inefficient policy decisions. ${ }^{10}$ Clare and Courtenay (2001) argue that minutes describing contentious discussion among central bank board members can heighten assetprice volatility, suggesting that copious information only confuses investors. More generally, van der Cruijsen, Eijffinger and Hoogduin (2008) suggest that agents may be confused by the large and increasing amount of information with which they are bombarded in a highly transparent regime. They suggest that excessive transparency may cause agents to realize how uncertain the central bank is about economic conditions and the efficacy of policy, in turn heightening volatility. Others ask whether requiring the central bank to provide detailed information about its intermediate targets, only to miss them, might similarly confuse and raise questions about the competence of policy makers. Thus Goodhart (2001) questions the efficacy of requiring the central bank to provide information on not just, inter alia, inflation forecasts but also its forecasts for the future path of the monetary policy instrument, on the grounds that this would so complicate decision making (board members would have to agree on an entire trajectory for their policy instrument at each decision point) as to potentially undermine effective decision making. ${ }^{11}$ Mishkin (2004) warns that a high degree of transparency might disrupt communication with the public, which would not easily understand that forecasts for the policy instrument are conditional on the future state of the economy, and which might misinterpret changes in the forecast (or deviations between forecast and realized rates) as the central bank reneging on its commitments.

\footnotetext{
${ }^{10}$ See Hamalainen (2001) for an early statement to this effect.

${ }^{11}$ Some central banks go part way toward indicating the prospective future path of interest rates; the Federal Reserve, for example, regularly signals its "bias" toward future interest-rate increases or reductions by issuing a "balance of risks" statement.
} 
We cannot resolve these debates here, but the evidence we present speaks to them. Specifically, in this paper, which is the latest in a series we have writing on the subject of central bank transparency, we undertake three tasks. ${ }^{12}$ First, we document changes in the prevalence of central bank transparency, updating our measures through 2006. Second, we analyze the determinants of the degree of transparency, focusing here on the role of political variables. Third, we examine the consequences for monetarypolicy outcomes such as inflation variability and inflation persistence. Here we probe for nonlinear effects of transparency on policy outcomes as a way of providing a provisional answer to Mishkin's (2004) question of whether "transparency can go too far." A methodologically significant aspect of our work is that we consider the determinants of transparency and the effects using a unified analytical framework. This means that we can use our analysis of the determinants to identify instrumental variables that address the concern that an observed correlation between outcomes and transparency reflects the impact of the former on the latter, rather than the other way around.

\section{Data}

Our indices of central bank transparency follow the work of Eijffinger and Geraats (2006). In contrast to earlier studies, most of which focused on particular aspects of transparency (for example, whether the central bank announced an explicit target for inflation), Eijffinger and Geraats acknowledged that transparency has multiple dimensions. The result is 15 subindices (detailed in the appendix) designed to capture the political, economic, procedural, policy and operational aspects of monetary policy

\footnotetext{
${ }^{12}$ See also Dincer and Eichengreen (2007).
} 
transparency. ${ }^{13}$ Political transparency denotes openness about policy objectives;

economic transparency openness about data, models and forecasts; procedural

transparency openness about the way decisions are taken; policy transparency openness

about the policy implications; and operational transparency openness about the

implementation of those decisions.

We draw our data from information on central banks' websites and in their

statutes, annual reports, and other published documents. We gather this information for as

large a number of central banks as possible (where Eijiffinger and Geraats looked at just

nine central banks). ${ }^{14}$ In addition, we gather the same information for every year from

1998 through 2006 . Where there was a change in some aspect of transparency over the

course of a calendar year, we take the value that prevailed for the largest portion of the

year. $^{15}$

We were able to assemble this information for 100 central banks. ${ }^{16}$ Most of the

omissions are central banks of micro-states: our sample includes the central banks of all

large, systemically significant countries. ${ }^{17}$

\footnotetext{
${ }^{13}$ The overall index thus runs from 0 to 15 . Adopting the same criteria used by these previous investigators has the advantage of facilitating comparisons across studies and frees us of suspicions that we have constructed our measures so as to maximize or minimize the impact of transparency.

${ }^{14}$ An earlier study by Bini-Smaghi and Gros (2001) also considered 15 aspects of central bank transparency, although they considered only four central banks. De Haan, Amtembrink and Waller (2004) developed a similar index for six countries, while De Haan and Amtembrink (2003) apply a similar approach to 15 countries. Siklos (2002) expands coverage to 20 central banks, all from advanced industrial countries. The most comprehensive previous study in terms of country coverage is Fry et al. (2000), although they construct indices only for 1998.

${ }^{15}$ Adding this time dimension was particularly challenging, since many central bank websites describe current practice but not that of prior years. For this we had to rely mainly on published documents. We were able to access a relatively complete run of these on the basis of holdings in the University of California and Joint IMF-World Bank libraries. We are grateful to the staff of the Joint Bank-Fund library for granting us access to their collection.

${ }^{16}$ This is the vast majority of central banks in the world (recall that there are more countries than there are central banks, given the existence of monetary unions, countries that have unilaterally adopted the currencies of other countries, etc.). A subsequent study by Crowe and Meade (2008) constructs measures of transparency very similar to our own but only since 2000 and for a much smaller (37 country) sample (their purpose being to compare measure of central bank transparency and independence).
} 
Table 1 shows the results by country and region. The most transparent central banks in 2006, according to our coding, were the Swedish Riksbank, the Reserve Bank of New Zealand, the Bank of England, the Bank of Canada, the Czech National Bank, the ECB, and the Central Bank of Hungary. We see here a number of countries that received high marks for transparency in previous studies (Sweden, New Zealand, the UK, Canada) but also others (the Czech Republic, Hungary), which is a reminder of the advantages of broad country coverage and of the fact that a number of countries with relatively opaque central banking practices have been moving in the direction of greater transparency. The six least transparent central banks were those of Aruba, Bermuda, Ethiopia, Libya, Saudi Arabia and Yemen. Table 2 shows our coding of the 15 individual components for these 13 countries as of 2006 .

More generally, we can compare different dimensions of central bank transparency. In 2006, 65 central banks received scores of 2 or more for political transparency (inter alia, providing a quantitative definition of their objectives to the public). ${ }^{18}$ Economic transparency (disclosing data, the policy model and forecasts) is less; only 5 central banks receive the highest possible rating. The picture is similar for procedural transparency (the release of minutes and votes), where only four central banks receive the highest possible score. And again for policy transparency (prompt announcement and comprehensive explanation of policy decisions), where only the Reserve Bank of New Zealand and the Swedish Riksbank receives the full score and the

\footnotetext{
${ }^{17}$ Among the omissions are Bolivia, Ecuador, Chad, Iran, and Afghanistan We are aware that this creates a form of sampling bias: we tend to oversample more transparent central banks. There exist econometric corrections for this bias (involving strong assumptions), although we have not implemented these yet. Our defense is that the number of consequential omissions is relatively slight.

${ }^{18}$ Up from 47 in 1998.

${ }^{20} 2006$ being the most recent year for which all the ancillary variables are currently available.
} 
Fed receive a score of 2.5. The only central bank receiving a perfect score of 3 for operational transparency (release of information about disturbances, control errors, etc.) is the Swedish Riksbank.

Taking unweighted averages of the countries making up a region (as in Table 1), we see the highest level of transparency in Australia-New Zealand, followed by Western Europe, Northern Europe, South East Asia, Southern Africa, and North America. That South East Asia and Southern Africa are scored as more transparent than North America is a figment of the unweighted averages. When we instead take GDP-weighted averages, as in Table 3, the most transparent regions as of 2006, in descending order, are Europe (led by Northern Europe), North America, Oceania and Southern Africa (dominated by South Africa); lower weights on its relatively transparent small economies causes South East Asia to drop down. Either way, the lowest levels of transparency, starting from the bottom, are those of Northern Africa, Southern Asia, Eastern Africa and Western Africa no surprises here.

Turning to trends over time, the average transparency score in our sample rose from 3.4 in 1998 and 5.4 in 2006. Strikingly, none of our 100 countries moved in the direction of less transparency. Figure 1 compares our measure of transparency in 1998 and 2006 (with 2006 on the vertical axis). There are only 10 countries on the diagonal, indicating no increase in transparency, while the remaining 90 cases are all above and to its left.

Figure 2 shows transparency by level of economic development (again, using weighted averages). Consistent with the preceding discussion, central banks in the advanced countries are more transparent than central banks in emerging markets (defined 
as middle-income countries with significant links to international financial markets), which in turn are more transparent than central banks in developing countries. Consistent with the implication of Figure 2 above, there have been increases in central bank transparency in all three country groups. Perhaps most strikingly, the increase among emerging markets is, on average, as large in absolute value as the increase among advanced countries; the corresponding increase among developing countries is smaller. Much of the increase in emerging markets is centered in the period following the Asian crisis and again in the early parts of the present decade.

\section{Determinants}

We now use regression analysis to further characterize differences in central bank transparency across countries and over time. Our goals here are to work toward an explanation for these variations and also to identify instruments for our analysis of the consequences of transparency. We proceed in two stages, first updating our previous findings and then pursuing a more detailed political-economy analysis.

We start with the 1998-2006 cross section, with all variables averaged over the period. ${ }^{20}$ We regress transparency on a vector of economic determinants: per capita income, inflation history (defined as the lagged log first difference of the consumer price index), the de facto exchange rate regime (the Reinhart-Rogoff 2003 version as updated by Eichengreen and Razo-Garcia 2006), and financial depth (defined as the ratio of M2 to GDP). In addition we include a range of potential political determinants: rule of law, political stability, voice and accountability, and government efficiency (all taken from Kaufmann, Kraay and Mastruzzi, 2007), together with a number of measures of 
democratic orientation (democracy and autocracy dummies and overall polity score) taken from the Polity IV data base. ${ }^{21}$ Variable definitions and sources are described in Appendix A.

Since the political variables are strongly correlated with one another, we include them one at a time. (This can be seen from the variance-covariance matrix presented in Appendix B.) The results (Table 4) suggest that per capita GDP is a robust determinant of overall transparency. There is good reason to think that that transparency should rise with the general level of economic and institutional development, for which per capita income proxies; this is also the measure of Figure 2 above. In addition, countries with more flexible exchange rates (where a larger value of the index denotes greater flexibility) tend to be more transparent in the conduct of monetary policy, as anticipated by our introduction - the absence of an exchange rate peg eliminating one traditional device for monitoring central bank actions. ${ }^{22}$ Finally, most of the political variables are significant and affect central bank transparency in plausible ways. ${ }^{23}$ Greater transparency characterizes central bank operations in countries that rank higher in terms of rule of law, that have more stable political systems, that have higher ratings in terms of voice and accountability, and that are more favorably regarded in terms of government efficiency. ${ }^{24}$ Countries with more open (democratic) political systems are also more likely to have

\footnotetext{
${ }^{21}$ Where we use variables from the Polity data base, we are forced to end the analysis in 2004.

${ }^{22}$ Readers may be concerned that the exchange rate regime is endogenous - that countries with experience with monetary policy transparency may be better able to operate regimes of grater flexibility. In the event, dropping the exchange-rate regime leaves the other results unchanged.

${ }^{23}$ The other variables do not approach statistical significance at conventional confidence levels. For what they are worth, the point estimates suggest that central banks of countries with better developed financial markets tend to be more transparent. Similarly, central banks of countries with a history of inflation tend to be more transparent, presumably as part of a credibility-building strategy. This is not something that would have been anticipated from the contrast between transparency in advanced and developing countries.

${ }^{24}$ When we include multiple political variables, it is voice and accountability and government efficiency that are most often significant at standard confidence levels.
} 
transparent central banks; it can be argued that the demand for political accountability is strong in such settings and that transparency is an important mechanism for accountability. $^{25}$

As a form of sensitivity analysis, we interacted the exchange rate regime with openness (exports as a share of GDP) and added openness as an additional regressor. The results (available from the authors on request) suggest that greater openness is associated with greater transparency if the country in question has a relatively flexible exchange rate but with less transparency if the country has a relatively rigid currency. This accords with intuition and casual observation.

Next we analyzed the determinants of the individual components of the transparency index to gain further insight into exactly how practice responds to these same economic and political factors. In Appendix $\mathrm{C}$ we report analogous regressions for each component of the transparency index. As can be seen there, per capita income and exchange rate flexibility are positively associated with each of the five components of the overall index. But the different components show different degrees of responsiveness to the various political factors. Political transparency is a positive function of political development as measured by voice and accountability. ${ }^{26}$ Economic transparency (the public disclosure of data, the policy model and forecasts), procedural transparency (the release of minutes and votes) and operational transparency (release of information about disturbances, control errors, etc.) are, in contrast, positively associated with a range of political factors (voice and accountability, government efficiency, democracy versus

\footnotetext{
${ }^{25}$ Note that the "polity" variable in the final column is the difference between "democracy" and "autocracy."

${ }^{26}$ Political transparency also appears to decline with financial depth, which is not a pattern for which we have an immediate explanation. Interestingly, other components such as economic and procedural transparency are positively associated with financial depth, as can be seen from the corresponding tables.
} 
autocracy, and the Polity score). related to a wide range of political factors. Policy transparency (prompt announcement and comprehensive explanation of policy decisions) stands out for being significantly related to each and every one of our measures of policies and institutions, not just those that affect economic, procedural and operational transparency but also political stability and rule of law. Thus, there are some subtle differences here in terms of which components of the transparency index are driving the observed correlation with political and institutional factors - the correlation appears to be weakest in the case of political transparency - but the results for the different measures are broadly consistent overall.

We can also use this specification to consider factors influencing trends in transparency. In Tables 5 and 6 we pool the annual observations and estimate fixedeffects models (including separate intercepts for each country). ${ }^{27}$ The estimates are now driven by the time series variation in the data; they thus tell us something about why central bank practice is evolving in the direction of greater transparency. The move to more flexible exchange rates (especially in open economies), per capita GDP (as a measure of general economic and social capability), rule of law and government efficiency appear to be the main variables driving the increase in transparency over time. While the democratic/autocratic nature of the political system helped to explain cross country patterns above, the spread of democracy does not appear to have much power for explaining within-country changes in monetary policy over time.

\footnotetext{
${ }^{27}$ The standard Hausman and Breusch-Pagan tests reject random effects and simple pooling in favor of fixed effects (the Hausman test statistic is reported at the foot of the tables). See also the further discussion below.

${ }^{29}$ But not between the level of inflation and transparency.
} 
The correlation of some of these political variables with central bank transparency—rule of law and government efficiency, in particular—will be useful when we consider the impact of transparency on economic and financial variables below. That is, while it is not hard to come up with an argument for why the transparency of monetary policy should affect inflation, financial markets, or the development of trade, it is harder to concoct a story for why it should have a first-order effect on, say, rule of law, which depends on the larger political and social setting and is the product of a country's history. It can thus be argued that such political variables satisfy the two criteria for a valid instrument: exogeneity and correlation with the explanatory variable of interest.

The fact that we will be relying on these measures as instruments also makes it important that we consider their correlation with the different components of the transparency index, as we did with the simple cross section above. There are some suggestive variations here. (See Appendix D.) When we focus on trends over time, policy transparency displays a correlation only with rule of law. Economic transparency appears to be affected only by political stability and rule of law. Procedural transparency responds only to government efficiency, voice and accountability and rule of law, operational transparency to government efficiency, political stability and rule of law. Political stability, in contrast, does not display a correlation with either rule of law or political stability, but it is moves in the expected manner with most of the other political and institutional variables. 


\section{Effects}

We now explore the effects of monetary policy transparency. Some previous studies (viz. Mishkin 2004) suggest that greater transparency should be associated with a reduction in uncertainty about future policy actions and thus with a reduction in inflation volatility. Consistent with the hypothesis, Demertzis and Hughes Hallett (2003), employing the Eijffinger-Geraats index for 2001, find a negative relationship between inflation variability and central bank transparency. ${ }^{29}$ Other studies (viz. Mankiw, Reis and Wolfers 2004; Levin, Natalucci and Piger 2004) suggest that there is less variability and dispersion in inflation expectations when central banks publish numerical targets for inflation. Still others suggest that greater transparency should be associated with lower inflation persistence, insofar as the credibility of monetary policy is enhanced and market participants do not extrapolate future inflation from current inflation. A study of the U.S., Sweden and the UK by Gurkaynak, Levin and Swanson (2005) provides indirect evidence on this question; it shows that in the U.S., where the authorities do not publish a target for inflation, there is a greater tendency for market participants to extrapolate inflation expectations from the recent behavior of inflation.

These studies are subject to important limitations. Most compare a relatively small set of not-obviously-representative central banks. In other words, central banks that are transparent about their policies are not likely to be selected randomly from the larger population. They focus on specific dimensions of transparency (publication of an inflation forecast, for example) in lieu of comprehensive measures. Others utilize indicators of transparency that are available only for one year. Virtually none of them 
acknowledge that central bank transparency is a choice variable than may itself be affected by the economic, financial and political environment.

Here we consider the impact on inflation variability and inflation persistence. In contrast to previous studies we acknowledge the endogeneity of monetary policy transparency by using the political variables utilized to explain the degree of transparency in Section 3 as instruments for transparency in this section's (second-stage) regressions. ${ }^{30}$ These second-stage coefficients are estimated using GMM to correct for heteroscedasticity and serial correlation in our panel-data set-up.

Table 7 reports the estimates for inflation variability. In each column we report the sum of squared residuals comparing the change in the point estimates with the loss of efficiency when instrumental variables are used; the change in the point estimates being relatively large, this supports our use of instrumental variables. In addition to the level of past inflation, which is positively related to inflation variability, the most important determinant is the (fitted value of the) central bank transparency index. This variable is negative and always significant at conventional confidence levels. ${ }^{31}$ This is consistent with theories suggesting that greater monetary-policy transparency allows the public to respond more quickly to policy actions, in turn discouraging the authorities from attempting to manipulate inflation in the pursuit of other objectives.

Table 8 considers inflation persistence. Transparency enters negatively and significantly when it is interested on its own (column 1), consistent with the notion that greater policy transparency allows the public to adjust more quickly, in turn limiting the incentive for the central bank to run inflationary policies in the effort to achieve

\footnotetext{
${ }^{30}$ Results using alternative instrument lists are discussed below and are available from the authors on request.

${ }^{31}$ Though the confidence level in question depends on which specific controls are included or excluded.
} 
objectives other than the maintenance of price stability. This result is also consistent with theories suggesting that greater monetary-policy transparency is a source of policy credibility, allowing the authorities to respond to events without exciting expectations of chronic inflation. However, the coefficient in question loses its significance as soon as other plausible determinants of inflation persistence are added to the specification. The relationship of transparency to inflation persistence is not as robust, in other words, as its relationship to inflation variability.

By adding a squared term in transparency we can also ask whether there are diminishing returns to central bank transparency ("whether transparency can go too far"). ${ }^{33}$ In the equation for inflation variability, transparency continues to enter with a significant negative coefficient as before, but transparency squared enters positively and also significantly. (See Table 9.) This suggests that increased transparency has the strongest effect on inflation variability for the most opaque central banks. ${ }^{34}$ The same broad pattern is evident in the regressions for inflation persistence, which show persistence declining with increased transparency but at a decelerating rate. In this case, however, the coefficients on the squared term designed to capture nonlinearities are not significantly different from zero at standard confidence levels. Again, the relationship between transparency and inflation persistence does not appear to be as robust as that between transparency and inflation variability.

\footnotetext{
${ }^{33}$ The squared term, like the level, is constructed from the fitted value of transparency derived from the first-stage regression.

${ }^{34}$ If the coefficients are taken literally they suggest that the benefits in terms of reducing inflation variability dissipate and inflation variability begins to rise with transparency when the index for the latter exceeds five, a suspiciously low threshold. Thus we do not want to push these particular point estimates too far.
} 
We explored the sensitivity of these results using alternative instrument lists, for example instrumenting transparency with rule of law alone instead of the entire vector of political and institutional measures The results were very similar, with stronger effects of transparency on inflation variability than inflation persistence and evidence of diminishing returns once transparency reached a certain threshold.

Since completing the first draft of this paper, we have seen the analysis of van der Cruijsen, Eijffinger and Hoogduin (2008), who similarly ask whether there are nonlinear effects of transparency on inflation persistence, with persistence declining initially as transparency rises, implying an optimal degree of central bank transparency. They estimate their model using our data and find significant coefficients on both the level and squared terms in transparency. They model persistence differently, using current inflation as the dependent variable and including the lagged inflation term interacted with transparency (and transparency squared) as an independent variable. They also include a different set of controls.

In fact, the consequential difference between their approach and ours is now how persistence is measured or what controls are included but simply whether or not the potential endogeneity of transparency (our key point) is taken into account. In column a of Table 11 we show our replication of their result. But when, as in column b, we use our instruments for transparency, the significance of the key coefficients dissolves. ${ }^{35}$ In columns $\mathrm{c}$ and $\mathrm{d}$ we substitute our version of the dependent variable, running OLS in column $\mathrm{c}$ and instrumenting transparency in column $\mathrm{d}$. In neither case is there evidence of a significant impact of transparency on inflation persistence.

\footnotetext{
${ }^{35}$ The versions of the equation run with instruments are again estimated by GMM. The two-stage least squares version simply applying the instruments to transparency yields the same results.
} 
We also explored more closely which component or components of the transparency index mainly drive the negative association with inflation variability and persistence. (Results are not reported to avoid a proliferation of tables but are available from the authors on request.) All five components continue to be associated with lower inflation variability and (less robustly) with lower inflation persistence when they are included one at a time (in each case being instrumented by rule of law). When we include all five simultaneously (employing a longer list of political instruments: rule of law, political stability, democratic accountability, government efficiency, and regulatory quality), there is an obvious multicolinearity problem. For what it is worth, these results suggest that operational transparency (openness about the implementation of those decisions), is mainly driving the reduction in inflation variability. This component enters negatively, and its coefficient differs from zero at the 99 percent confidence level. None of the other components have coefficients that differ from zero at standard confidence levels. $^{36}$

An alternative is to test whether the five dimensions of transparency matter as a group. To this end we constructed the principal components of our measures of the five dimensions of transparency. We entered into the equation the first and second principal components (where the first explains 34 per cent of the variation in the group, the second 12 per cent). When substituted for the various individual measures of transparency, the two principal components enter negatively and significantly in the equation for inflation variability (they are significant as a pair and the second principal component is

\footnotetext{
${ }^{36}$ The coefficient on the fifth component enters with a t-statistic of 4.2. None of the other coefficients have t's in excess of one.
} 
significant individually), but they enter insignificantly in the equation for inflation persistence, consistent with the results we report above.

\section{Conclusion}

Greater transparency of central bank operations is the most dramatic recent change in the conduct of monetary policy. We understand this as a response to changes in the monetary policy environment. It is a way of ensuring the accountability of policy makers when the traditional mechanisms for doing so - public monitoring of compliance with an exchange rate commitment and direct oversight by a government with formal control - are in decline, reflecting the shift to flexible exchange rates and central bank independence.

In this paper we have presented new data on the extent of the trend and its effects. The trend is general - a large number of central banks have moved in the direction of greater transparency in recent years. The question is whether it will prove durable or be a passing phase. In part, the answer depends on the consequences. Our preliminary analysis suggests broadly favorable impacts on inflation variability, but less evidence of an impact on inflation persistence. Still, if institutional arrangements that produce favorable results retain public support, then this suggests that the trend toward greater monetary policy transparency is here to stay.

The other way of approaching this question is to ask whether the changes in the policy environment that precipitated the move toward greater transparency might themselves be rolled back. We see the abandonment of pegged exchange rates as a response to financial liberalization and greater central bank independence as a way of 
insulating the conduct of monetary policy from short-term political pressures in democracies. If financial globalization and political democratization are here to stay, as we suspect, then so too is greater transparency in the conduct of monetary policy. 


\section{Data Appendix}

This appendix describes the construction of the transparency index. The index is the sum of the scores for answers to the fifteen questions below $(\min =0, \max =15)$.

\section{Political Transparency}

Political transparency refers to openness about policy objectives. This comprises a formal statement of objectives, including an explicit prioritization in case of multiple goals, a quantification of the primary objective(s), and explicit institutional arrangements. (a) Is there a formal statement of the objective(s) of monetary policy, with an explicit prioritization in case of multiple objectives?

No formal objective $(\mathrm{s})=0$.

Multiple objectives without prioritization $=1 / 2$.

One primary objective, or multiple objectives with explicit priority $=1$.

(b) Is there a quantification of the primary objective(s)?

$$
\begin{aligned}
& \text { No }=0 . \\
& \text { Yes }=1 .
\end{aligned}
$$

(c) Are there explicit contacts or other similar institutional arrangements between the monetary authorities and the government?

No central bank contracts or other institutional arrangements $=0$.

Central bank without explicit instrument independence or $\operatorname{contract}=1 / 2$.

Central bank with explicit instrument independence or central bank contract although possibly subject to an explicit override procedure $=1$. 


\section{Economic Transparency}

Economic transparency focuses on the economic information that is used for monetary policy. This includes economic data, the model of the economy that the central bank employs to construct forecasts or evaluate the impact of its decisions, and the internal forecasts (model based or judgmental) that the central bank relies on.

(a) Is the basic economic data relevant for the conduct of monetary policy publicly available? (The focus is on the following five variables: money supply, inflation, GDP, unemployment rate and capacity utilization.)

Quarterly time series for at most two out of the five variables $=0$.

Quarterly time series for three or four out of the five variables $=1 / 2$.

Quarterly time series for all five variables $=1$.

(b) Does the central bank disclose the macroeconomic model(s) it uses for policy analysis?

$$
\begin{aligned}
& \text { No }=0 . \\
& \text { Yes }=1 .
\end{aligned}
$$

(c) Does the central bank regularly publish its own macroeconomic forecasts?

No numerical central bank forecasts for inflation and output $=0$.

Numerical central bank forecasts for inflation and/or output published at less than quarterly frequency $=1 / 2$.

Quarterly numerical central bank forecasts for inflation and output for the medium term (one to two years ahead), specifying the assumptions about the policy instrument (conditional or unconditional forecasts) $=1$.

\section{Procedural Transparency}


Procedural transparency is about the way monetary policy decisions are taken.

(a) Does the central bank provide an explicit policy rule or strategy that describes its monetary policy framework?

$$
\begin{aligned}
& \text { No }=0 . \\
& \text { Yes }=1 .
\end{aligned}
$$

(b) Does the central bank give a comprehensive account of policy deliberations (or explanations in case of a single central banker) within a reasonable amount of time?

No or only after a substantial lag (more than eight weeks) $=0$.

Yes, comprehensive minutes (although not necessarily verbatim or attributed) or explanations (in case of a single central banker), including a discussion of backward and forward-looking arguments $=1$.

(c) Does the central bank disclose how each decision on the level of its main operating instrument or target was reached?

No voting records, or only after substantial lag (more than eight weeks) $=0$.

Non-attributed voting records $=1 / 2$.

Individual voting records, or decision by single central banker $=1$.

\section{Policy Transparency}

Policy transparency means prompt disclosure of policy decisions, together with an explanation of the decision, and an explicit policy inclination or indication of likely future policy actions.

(a) Are decisions about adjustments to the main operating instrument or target announced promptly? 
No or only after the day of implementation $=0$.

Yes, on the day of implementation $=1$.

(b) Does the central bank provide an explanation when it announces policy decisions?

No $=0$.

Yes, when policy decisions change, or only superficially $=1 / 2$.

Yes, always and including forwarding-looking assessments $=1$.

(c) Does the central bank disclose an explicit policy inclination after every policy meeting or an explicit indication of likely future policy actions (at least quarterly)?

$$
\begin{aligned}
& \text { No }=0 . \\
& \text { Yes }=1 .
\end{aligned}
$$

\section{Operational Transparency}

Operational transparency concerns the implementation of the central bank's policy actions. It involves a discussion of control errors in achieving operating targets and (unanticipated) macroeconomic disturbances that affect the transmission of monetary policy. Furthermore, the evaluation of the macroeconomic outcomes of monetary policy in light of its objectives is included here as well.

(a) Does the central bank regularly evaluate to what extent its main policy operating targets (if any) have been achieved?

No or not very often (at less than annual frequency) $=0$.

Yes but without providing explanations for significant deviations $=1 / 2$.

Yes, accounting for significant deviations from target (if any); or, (nearly) perfect control over main operating instrument/target $=1$. 
(b) Does the central bank regularly provide information on (unanticipated)

macroeconomic disturbances that affect the policy transmission process?

No or not very often $=0$.

Yes but only through short-term forecasts or analysis of current macroeconomic developments (at least quarterly) $=1 / 2$.

Yes including a discussion of past forecast errors (at least annually) $=1$.

(c) Does the central bank regularly provide an evaluation of the policy outcome in light of its macroeconomic objectives?

No or not very often (at less than annual frequency) $=0$.

Yes but superficially $=1 / 2$.

Yes, with an explicit account of the contribution of monetary policy in meeting the objectives $=1$. 


\section{References}

Ball, Lawrence and Niamh Sheridan (2005), "Does Inflation Targeting Matter?" in Ben Bernanke and Michael Woodford (eds), The Inflation-Targeting Debate, Chicago: University of Chicago Press, pp.249-278.

Barro, Robert and Roger Gordon (1983), "A Positive Theory of Monetary Policy in a Natural Rate Model," Journal of Political Economy 91, pp. 589-610.

Bini-Smaghi, Lorenzo and Daniel Gros (2001), "Is the ECB Sufficiently Accountable and Transparent?" European Network of Economic Policy Research Institutes Working Paper no. 7 (September).

Carpenter, Seth (2004), "Transparency and Monetary Policy: What does the Academic Literature tell Policymakers?," Finance and Economics Discussion Series 2004-35. Washington: Board of Governors of the Federal Reserve System.

Cecchetti, Steven and Stefan Krause (2001), "Central Bank Structure, Policy Efficiency and Macroeconomic Performance: Exploring the Empirical Relationships," NBER Working Paper no. 8354 (July).

Chadha, Jagjit and Charles Nolan (2001), "Inflation Targeting, Transparency and Interest Rate Volaility: Ditching 'Monetary Mystique' in the UK," Journal of Macroeconomics 23, pp. 349-366.

Chortareas, Georgios, David Stasavage and Gabriel Sterne (2001), "Does It Pay to be Transparent? International Evidence from Central Bank Forecasts,” Bank of England Working Paper no. 143.

Christiano, Larence J. and Christopher Gust (2000), “The Expectations Trap," Economic Perspectives of the Federal Reserve Bank of Chicago, issue Q II, pp.21-39.

Clare, A. and R. Courtenay (2001), "Assessing the Impact of Macroeconomic News Announcements on Securities Prices Under Different Monetary Policy Regimes," Bank of England Working Paper no. 125 (March).

Clarida, Richard, Jordi Gali and Mark Gertler (2000), "Monetary Policy Rules and Macroeconomic Stability: Evidence and Some Theory," Quarterly Journal of Economics 115, pp.147-180.

Crowe, Christopher and Ellen Meade (2008), "Central Bank Independence and Transparency: Evolution and Effectiveness,” IMF Working Paper 08/119 (May). 
De Haan, Jakob and Fabian Amtenbrink (2002), "A Non-Transparent European Central Bank: Who is to Blame?" Paper presented to the conference on Monetary Policy Transparency, London: Bank of England (May).

De Haan, Jakob, Fabian Amtenbrink and Sandra Waller (2004), "The Transparency and Credibility of the European Central Bank," Journal of Common Market Studies 42, pp. 775-794.

Demertzis, Maria and Andrew Hughes Hallett (2003), “Central Bank Transparency in Theory and Practice," unpublished manuscript, Netherlands Bank and Vanderbilt University (January).

Dincer, Nergiz and Barry Eichengreen (2007), "Central Bank Transparency: Where, Why and With What Effects?” NBER Working Paper no.13003.

Eichengreen, Barry, Mark Watson and Richard Grossman (1985), "Bank Rate Policy Under the Interwar Gold Standard: A Dynamic Probit Model," Economic Journal 95, pp.725-745.

Eijffinger, Sylvester and Petra Geraats (2006), "How Transparent are Central Banks?" European Journal of Political Economy 22, pp.1-22.

Eijffinger, Sylvester, Marco Hoeberichts and Eric Schaling (2000), “A Theory of Central Bank Accountability,” CEPR Discussion Paper no. 2354 (January).

Faust, Jon and Lars Svensson (2001), "Transparency and Credibility: Monetary Policy with Unobservable Goals," International Economic Review 42, pp. 369-397.

Fry, M, D. Julius, L. Mahadeva, S. Roger and G. Sterne (2000), "Key Issues in the Choice of a Monetary Policy Framework," in L. Mahadeva and G. Sterne (eds), Monetary Policy Frameworks in a Global Context, London: Routledge, pp. 1-216.

Geraats, Petra M. (2002a), "Why Adopt Transparency? The Publication of Central Bank Forecasts," unpublished manuscript, University of Cambridge (July).

Geraats, Petra M. (2002b), “Central Bank Transparency,” Economic Journal 112, pp. F532-565.

Geraats, Petra M. (2005), "Political Pressures and Monetary Mystique," Cambridge Working Papers in Economics no. 0557 (December).

Geraats, Petra M. (2006), "Transparency of Monetary Policy: Theory and Practice," CESifo Economic Studies 52, pp.111-152.

Gersbach, Hans (1998), "Financial Intermediation with Market Side Switching," unpublished manuscript, University of Heidelberg. 
Goodhart, Charles (2001), "Monetary Transmission Lags and the Formulation of the Policy Decision on Interest Rates," Federal Reserve Bank of St. Louis Review (July/August), pp.165-181.

Greider, William (1987), Secrets of the Temple: How the Federal Reserve Runs the Country, New York: Simon \& Schuster.

Gruner, H. P. (2002), "How Much Should Central Banks Talk? - A New Argument," Economics Letters 77, pp. 195-198.

Gurkaynak, Refet, Andrew Levin and Eric Swanson (2005), "Inflation Targeting and the Anchoring of Long-Run Inflation Expectations: International Evidence from Daily Bond Yield Data," Paper prepared for the Riksbank Workshop on Inflation Targeting, Stockholm (June).

Haldane, Andrew and Vicky Read (2000), "Monetary Policy Surprises and the Yield Curve," Bank of England Working Paper no. 106.

Hamalainen, Sirkka (2001), “The ECB’s Monetary Policy - Accountability, Transparency and Communication," Speech delivered to the conference on "Old Age, New Economy, and Central Banking," www.ecb.org (14 September).

Jensen, Henrik (2002), "Optimal Degrees of Transparency in Monetary Policymaking," Scandinavian Journal of Economics 104, pp.399-424.

Kaufmann, Daniel, Aart Kraay, and Massimo Mastruzzi (2007), "Governance Matters VI: Governance Indicators for 1996-2006,” World Bank Policy Research Working Paper, No. 4280, the World Bank (July).

Kuttner, Kenneth and Adam Posen (2000), "Inflation, Monetary Transparency, and G3 Exchange Rate Volatility,” Working Paper 00-6, Washington, D.C.: Institute for International Economics (July).

Levin, Andrew, Fabio Natalucci and Jeremy Piger (2004), "Explicit Inflation Objectives and Macroeconomic Outcomes,” ECB Working Paper no.383 (August).

Mankiw, Gregory, Ricardo Reis and Justin Wolfers (2004), "Disagreement About Inflation Expectations," NBER Macroeconomics Annual 2003, pp.209-247.

Mishkin, Frederic (2004a), “Can Central Bank Transparency Go Too Far?” NBER Working Paper no.10829 (October).

Mishkin, Frederic (2004b), "Why the Fed Should Adopt Inflation Targeting," International Finance 7, pp.117-127. 
Morris, Stephen and Hyun Shin (2002), "The Social Value of Public Information," American Economic Review 92, pp.1521-1534.

Morris, Stephen and Hyun Shin (2005), "Central Bank Transparency and the Signal Value of Prices," Brookings Papers on Economic Activity 2, pp.1-66.

Muller, Philippe and Murray Zelmer (1999), "Greater Transparency in Monetary Policy: Impact on Financial Markets," Bank of Canada Technical Report 86, Ottawa: Bank of Canada (August).

Reinhart, Carmen, Kenneth Rogoff and Miguel Savastano (2003), "Debt Intolerance," Brookings Papers on Economic Activity 1, pp.1-74.

Shaling, Eric and Charles Nolan (1998), "Monetary Policy Uncertainty and Inflation: The Role of Central Bank Accountability,” De Economist 146, pp. 585-602.

Siklos, Pierre (2002), The Changing Face of Central Banking: Evolutionary Trends Since World War II, New York: Cambridge University Press.

Sørensen J.R. (1991) "Political Uncertainty and Macroeconomic Performance," Economics Letters 37, 4377-381

Van der Cruijsen, Carin A.B., Sylvester C.W. Eijffinger and Lex H. Hoogduin (2008), “Optimal Central Bank Transparency," unpublished manuscript, De Nederlandsche Bank, Tilberg University and University of Amsterdam (June).

Walsh, C. E. (1999), “Announcements, Inflation Targeting and Central Bank Incentives,"Economica 66, pp. 255-69. 
Figure 1. Comparison of Transparency in 1998 and 2006

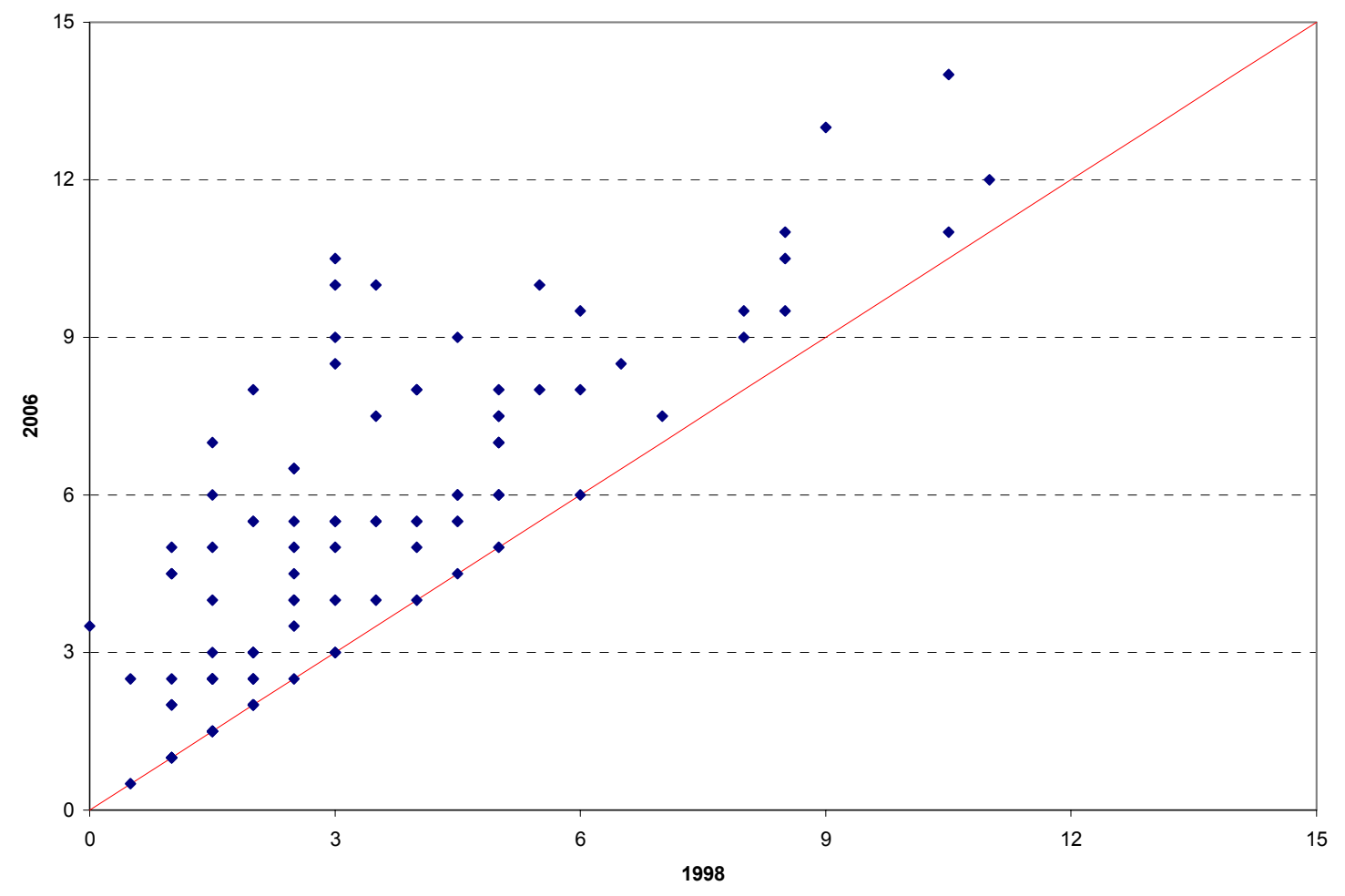


Figure 2. Trends in Transparency by Level of Economic Development: Weighted Averages

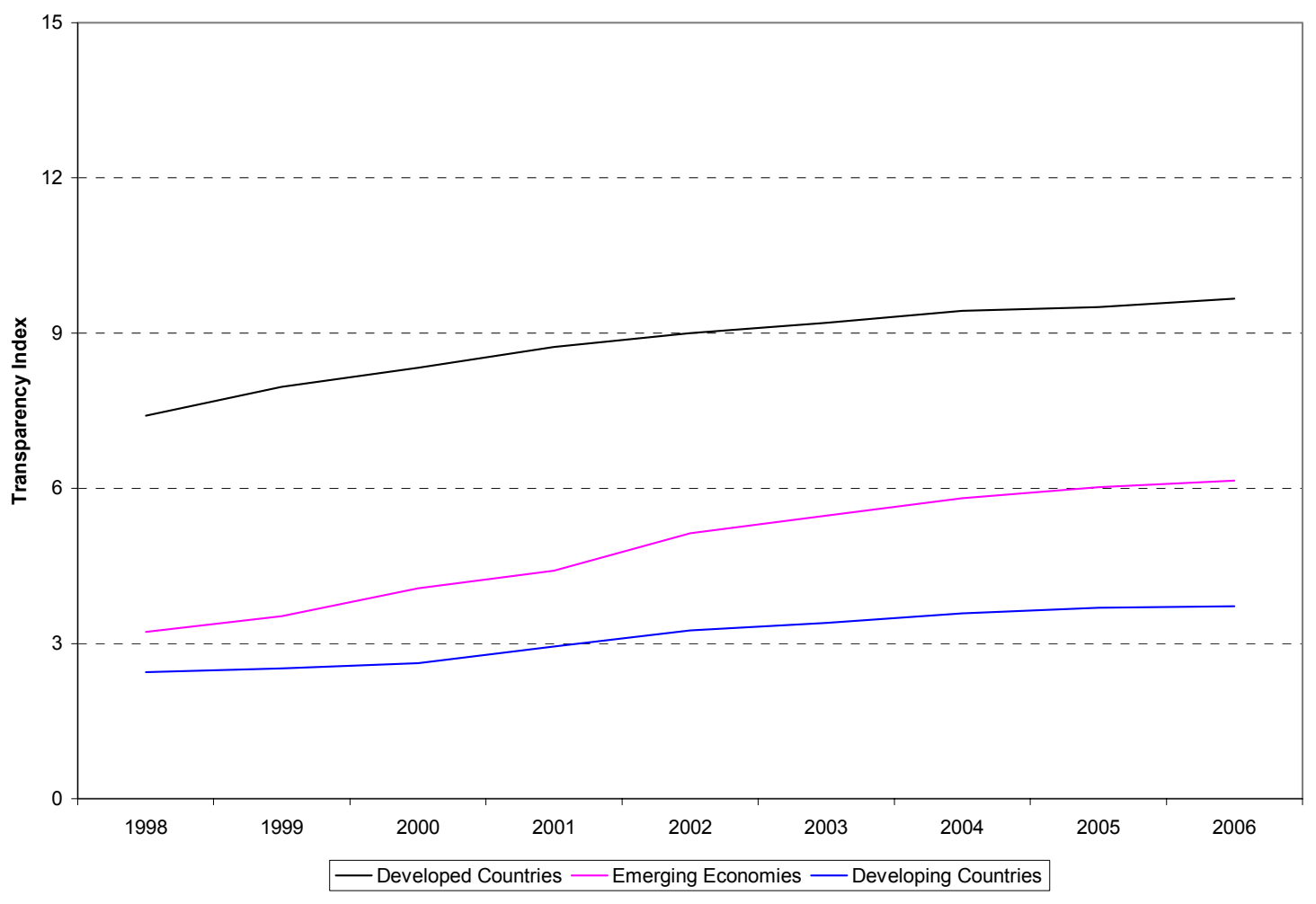




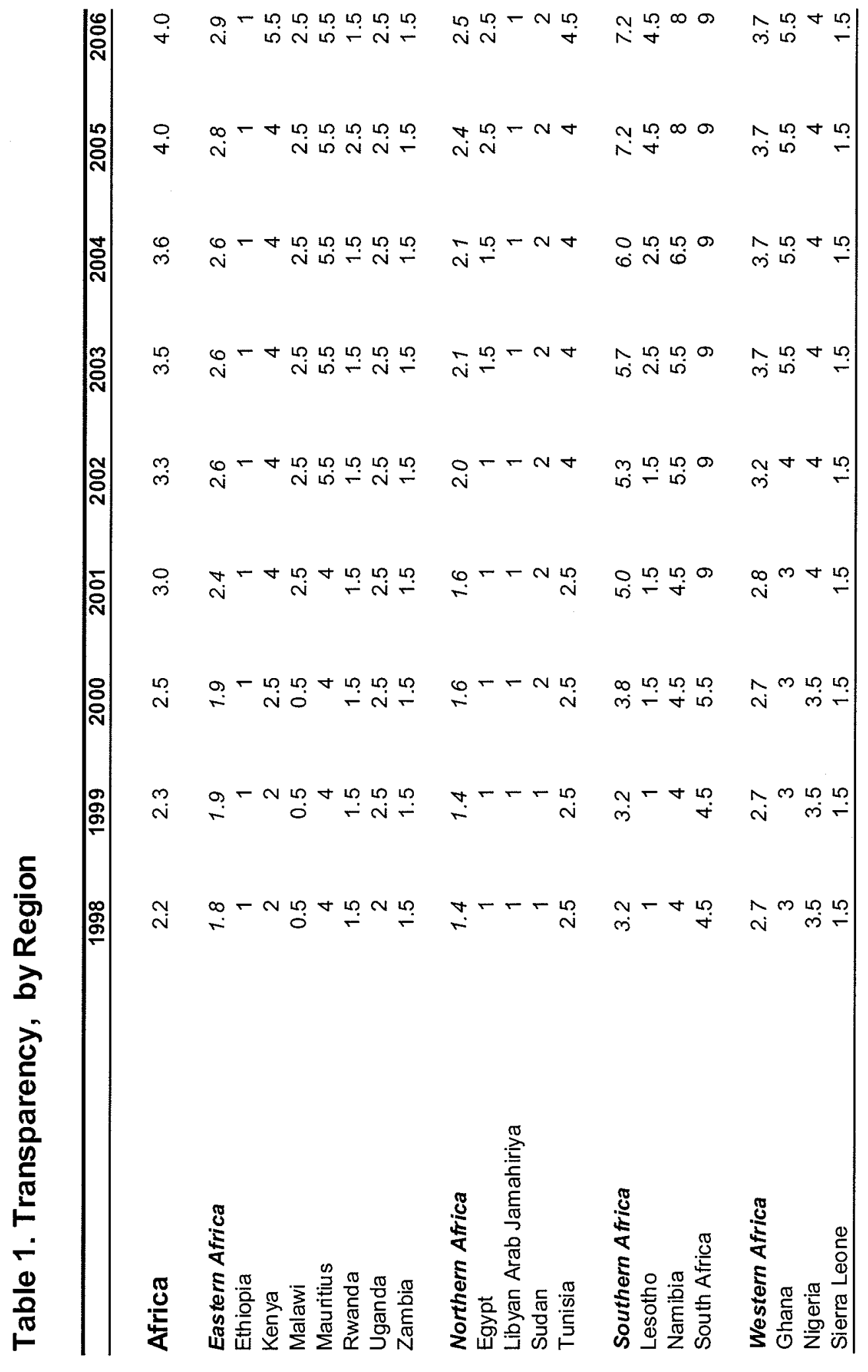




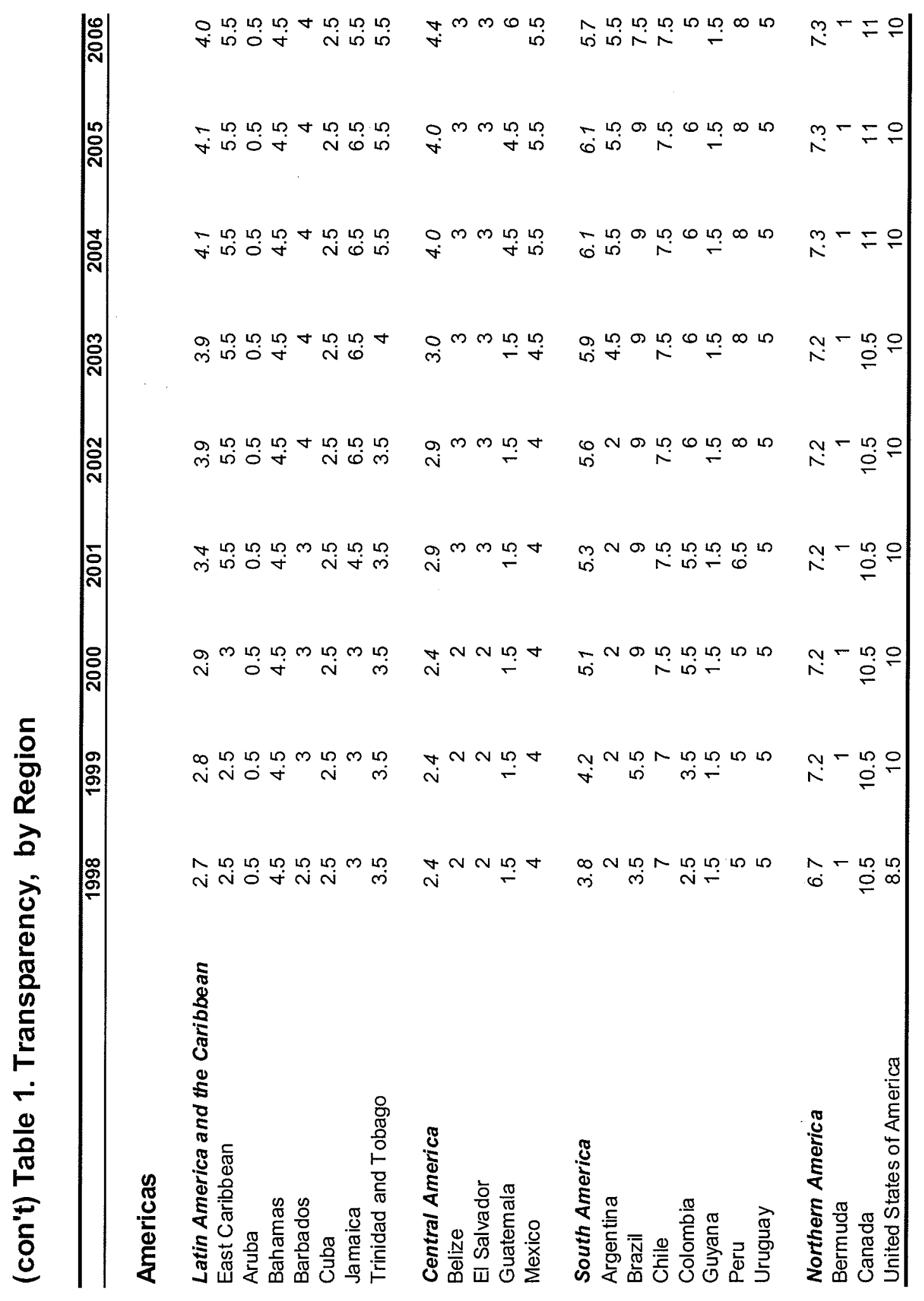




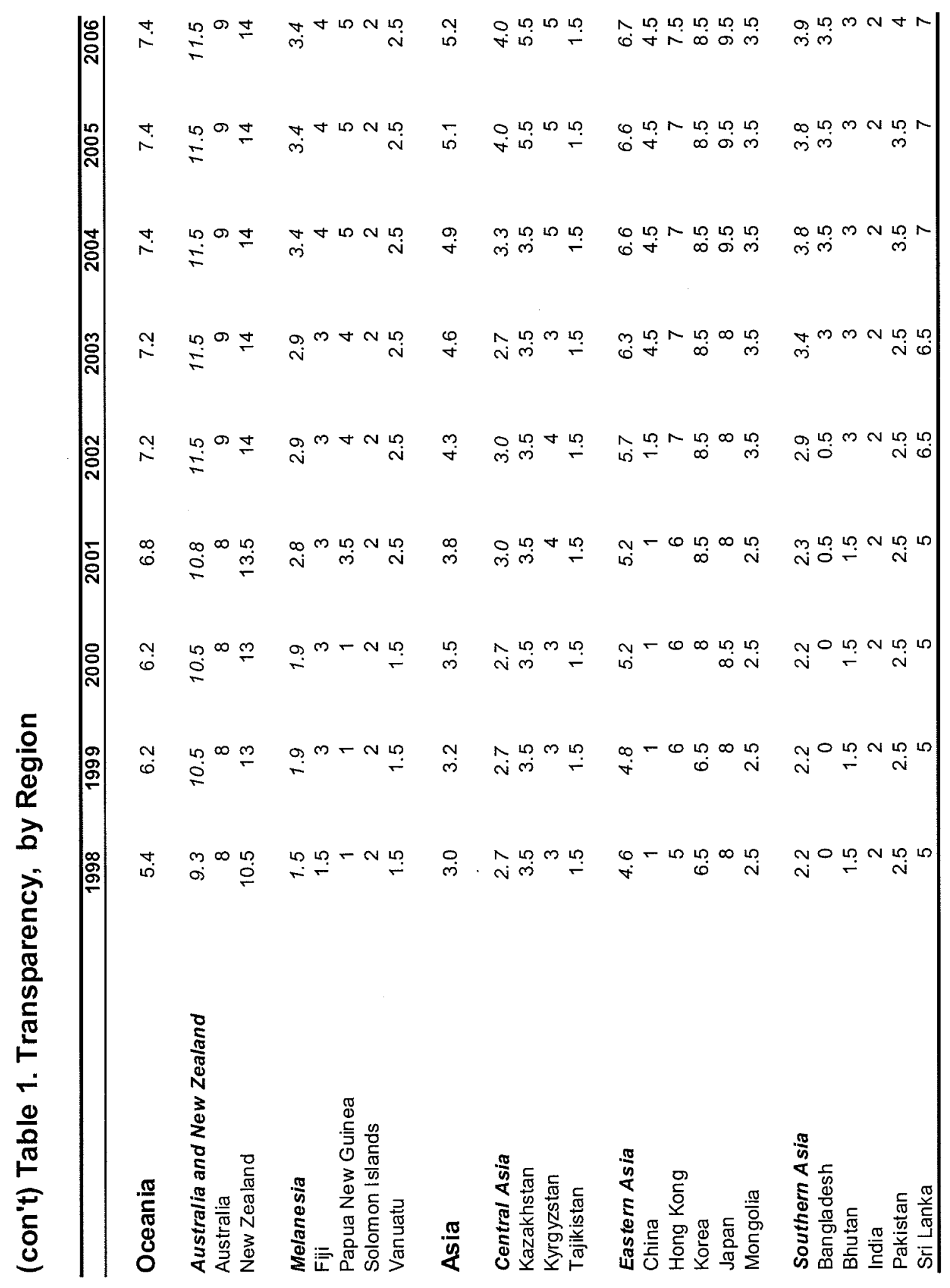




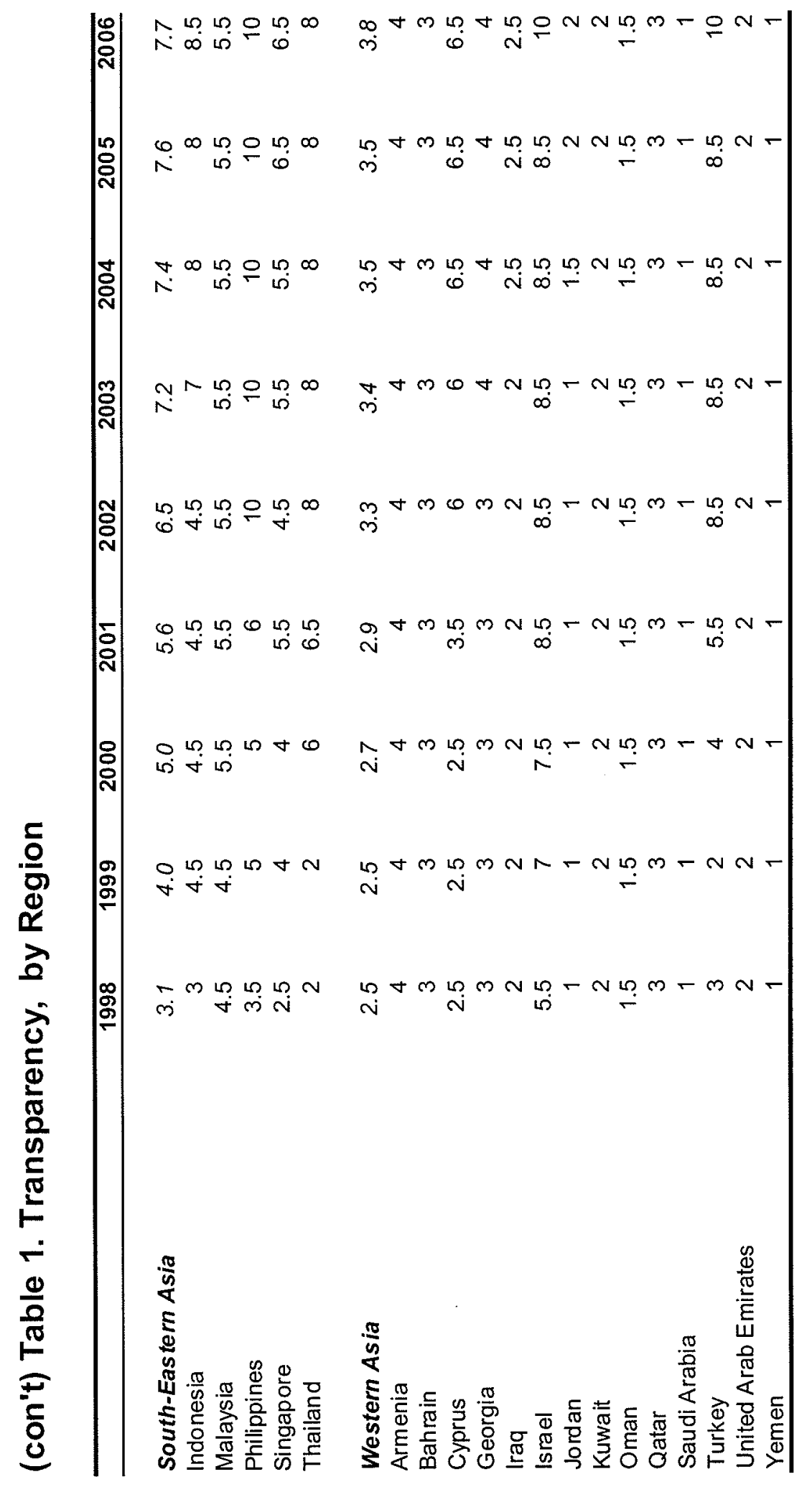




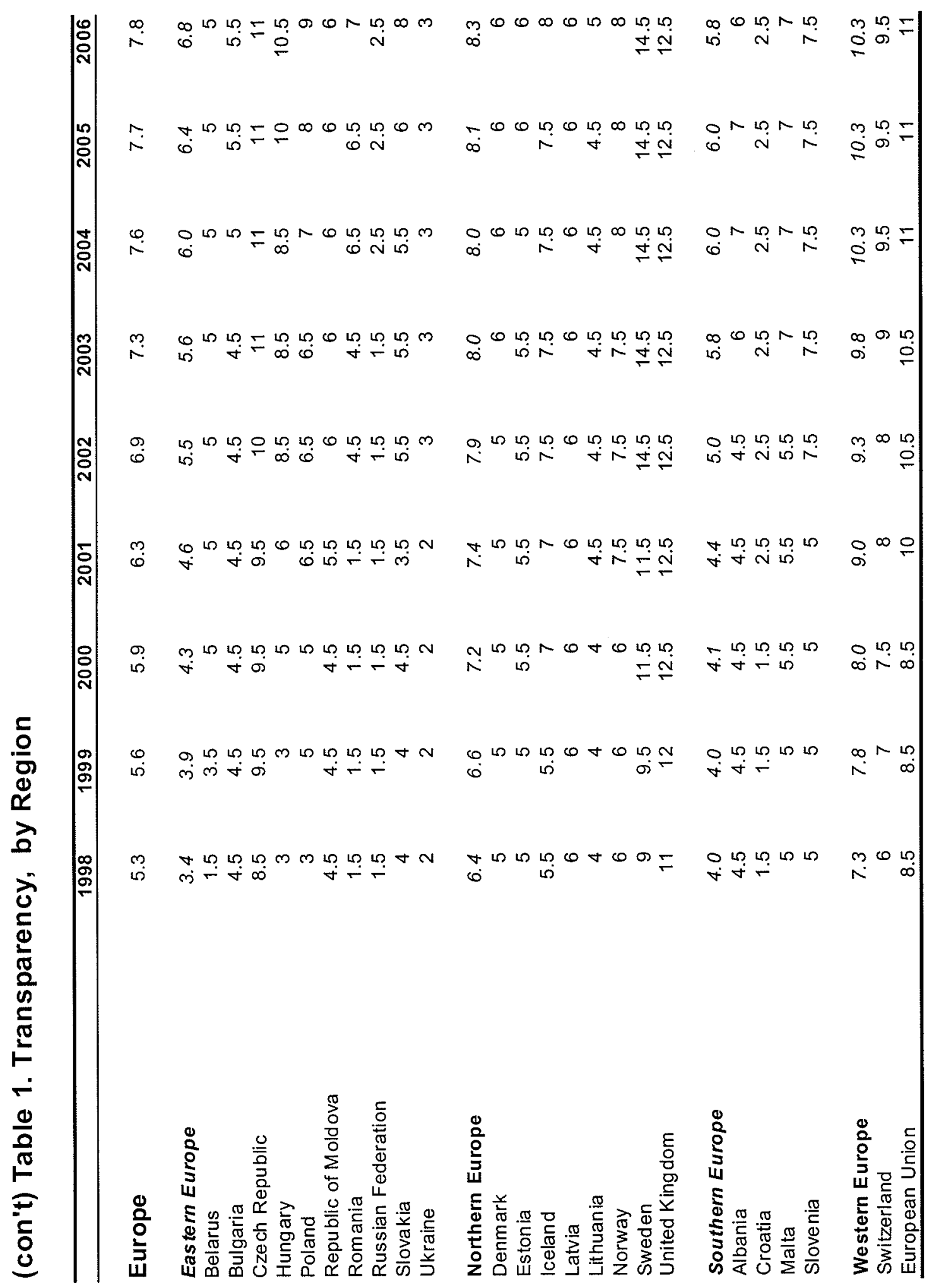




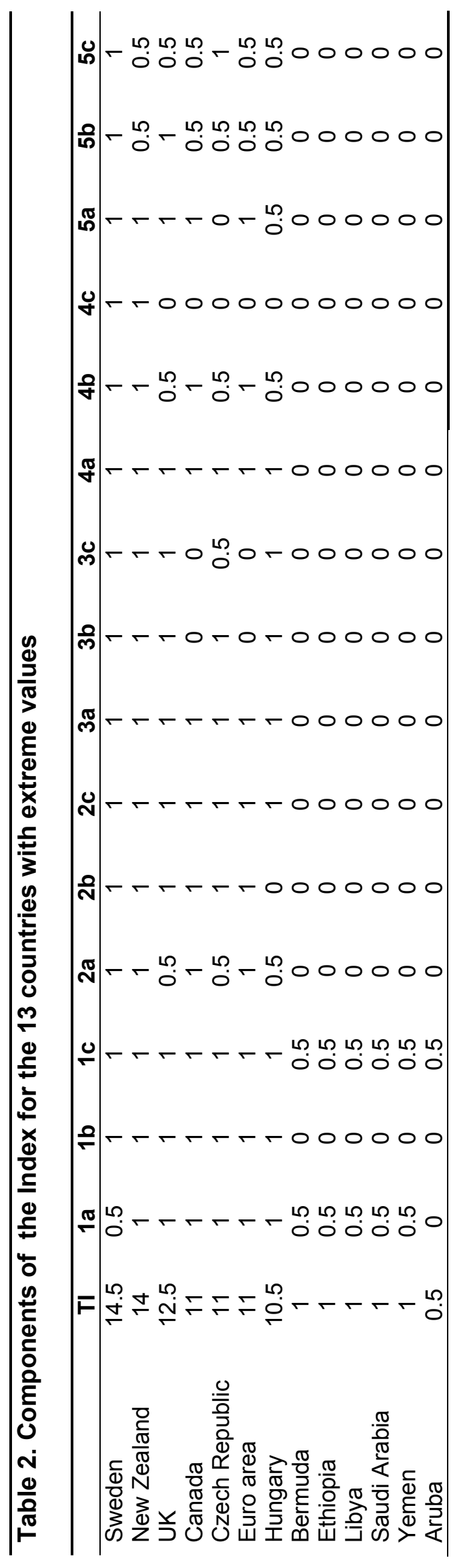




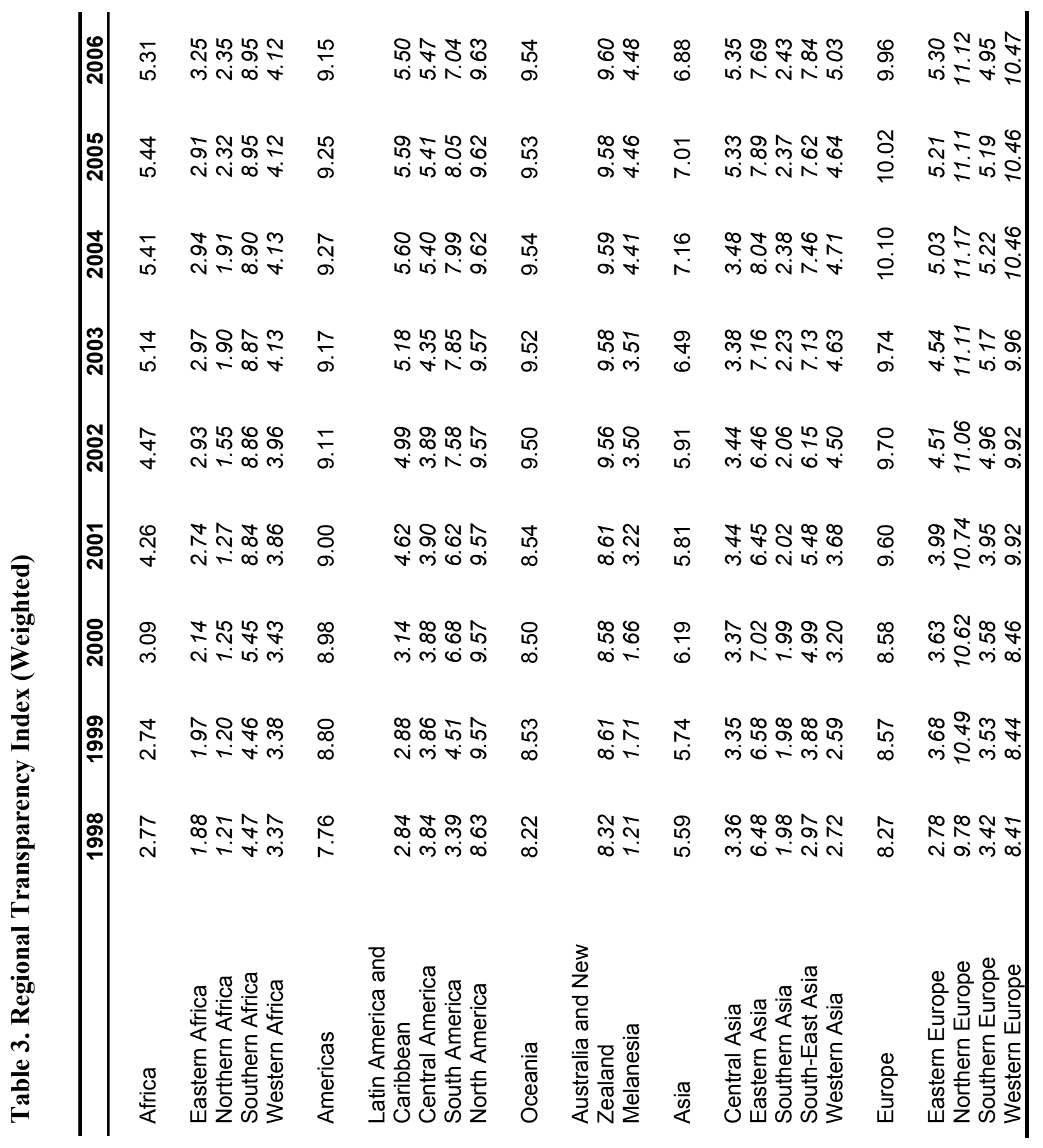




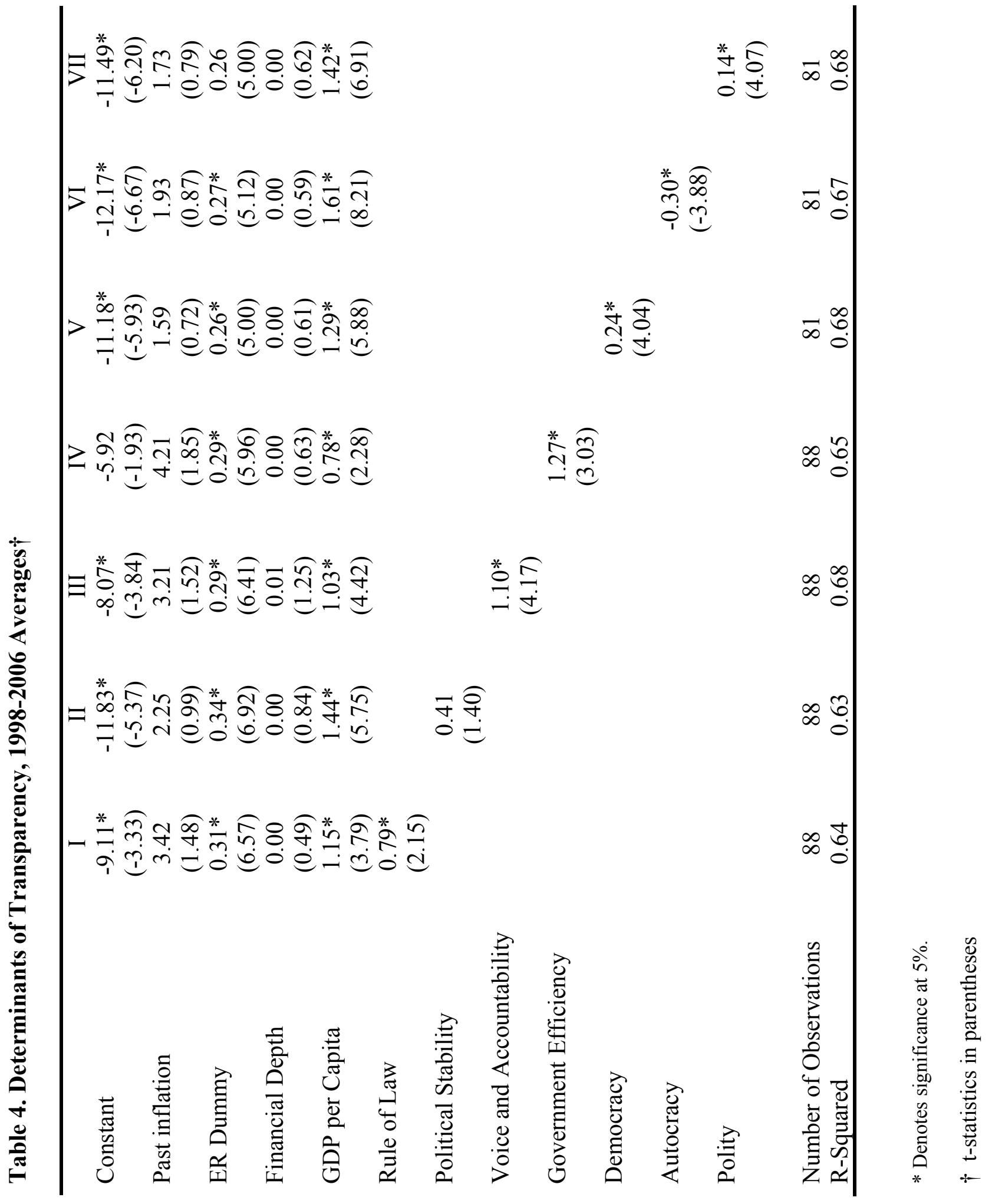




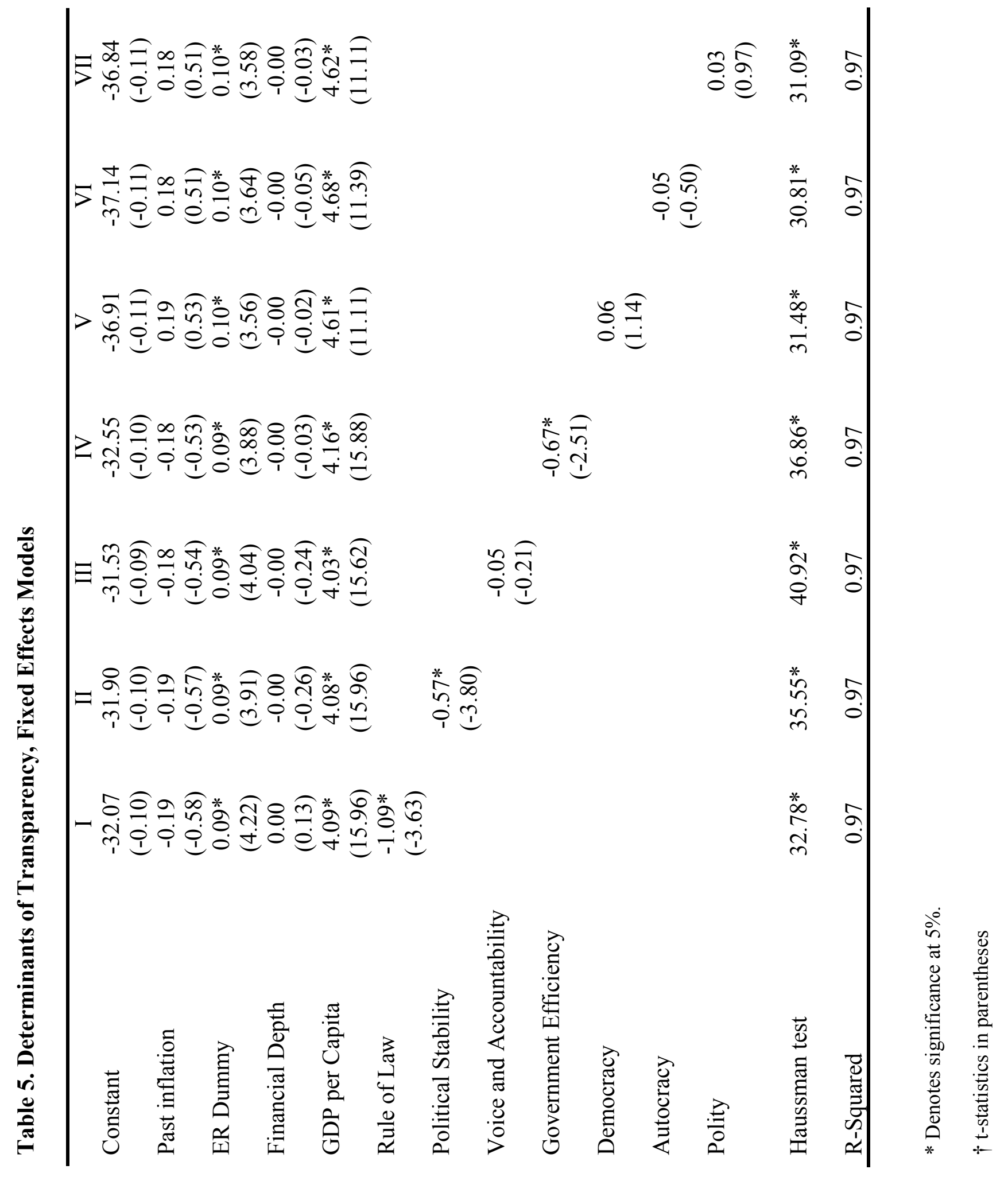




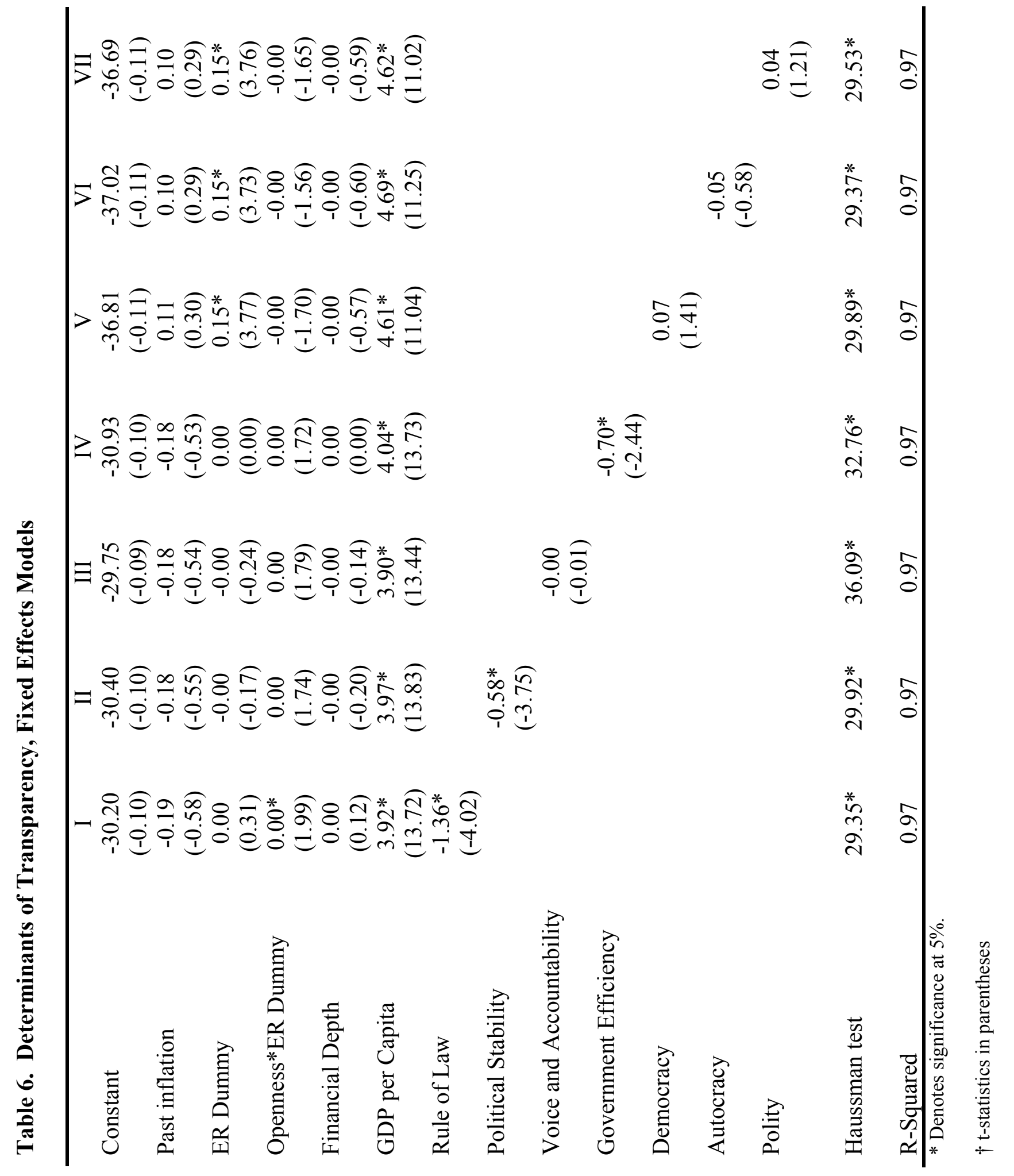




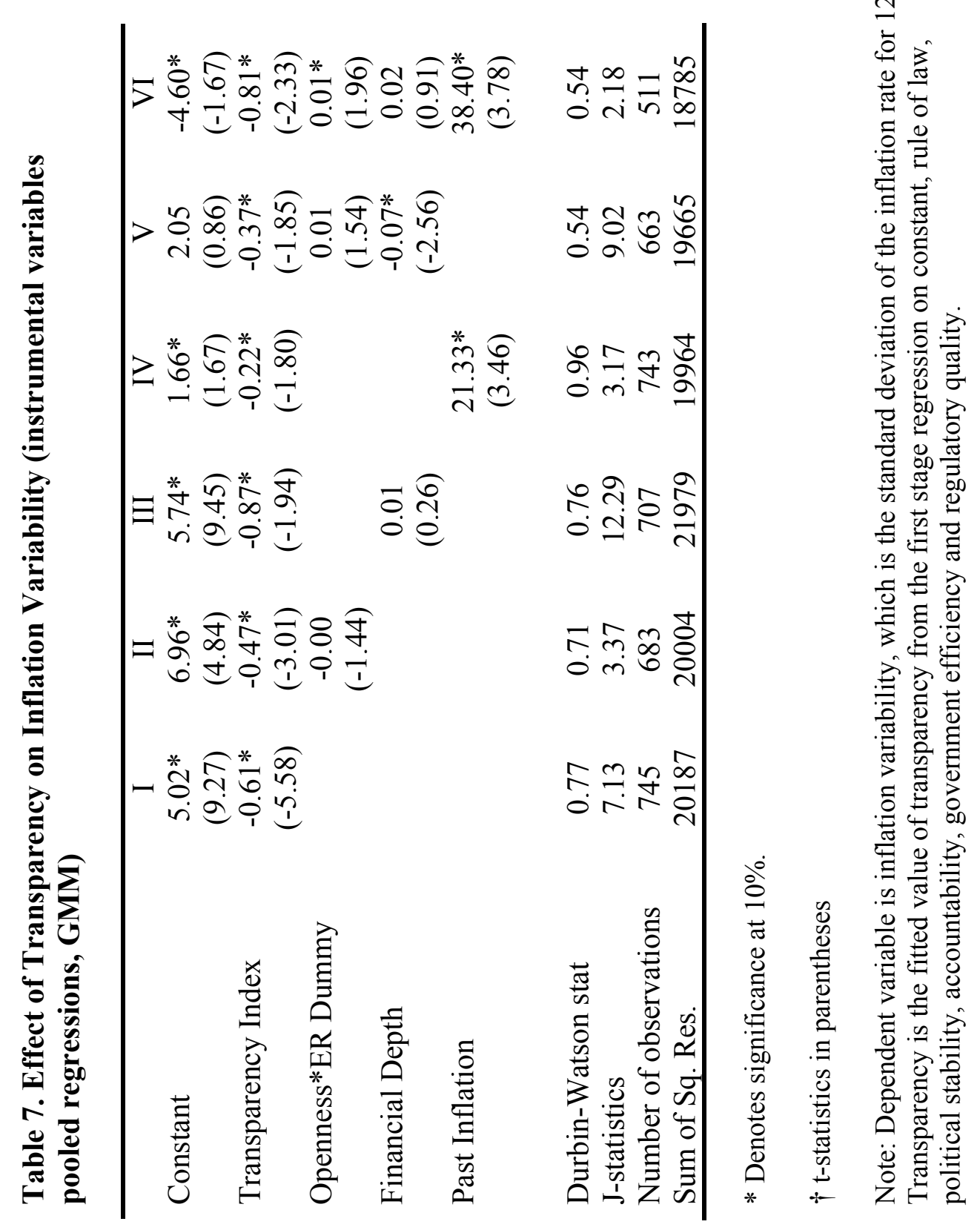




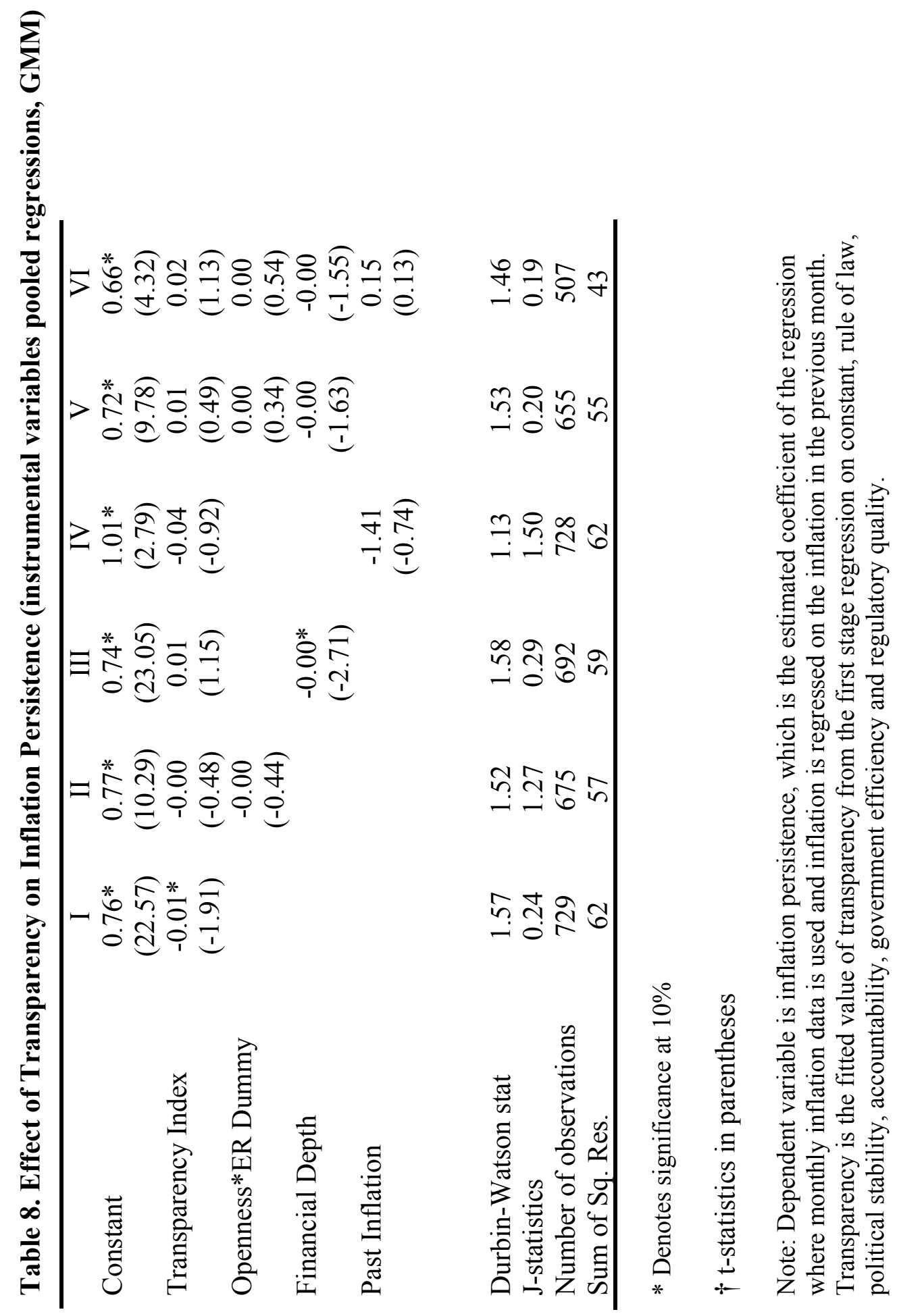




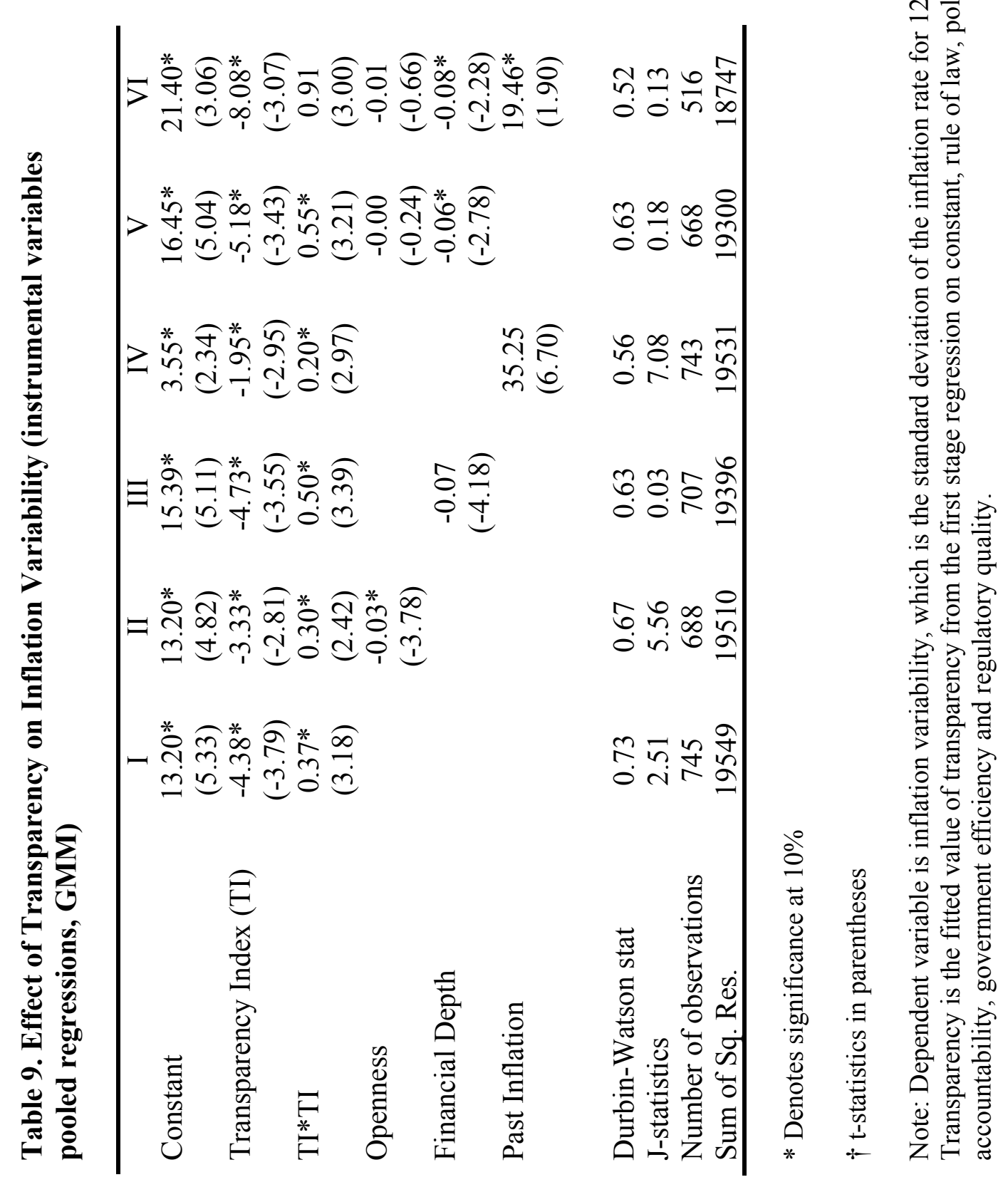




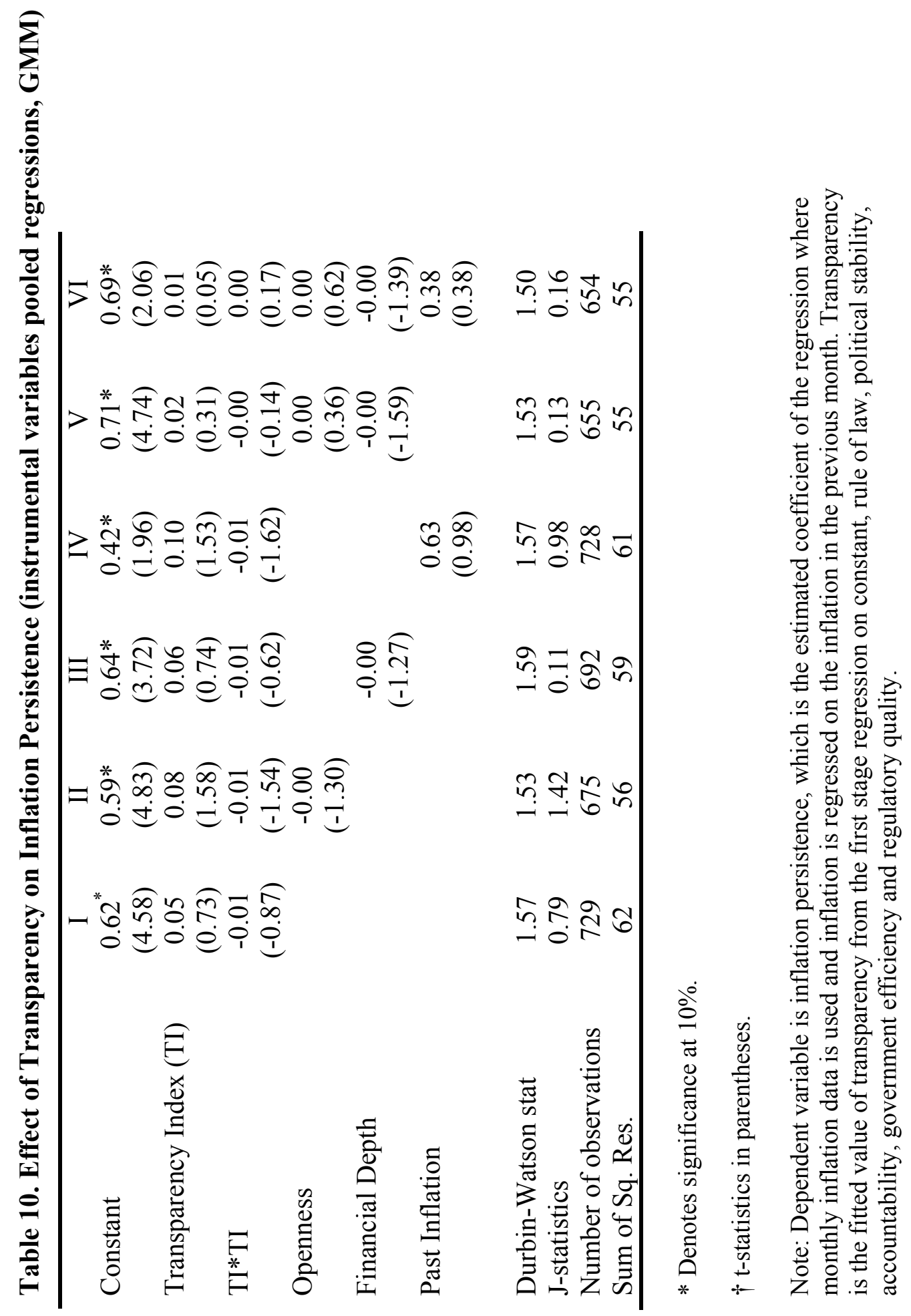



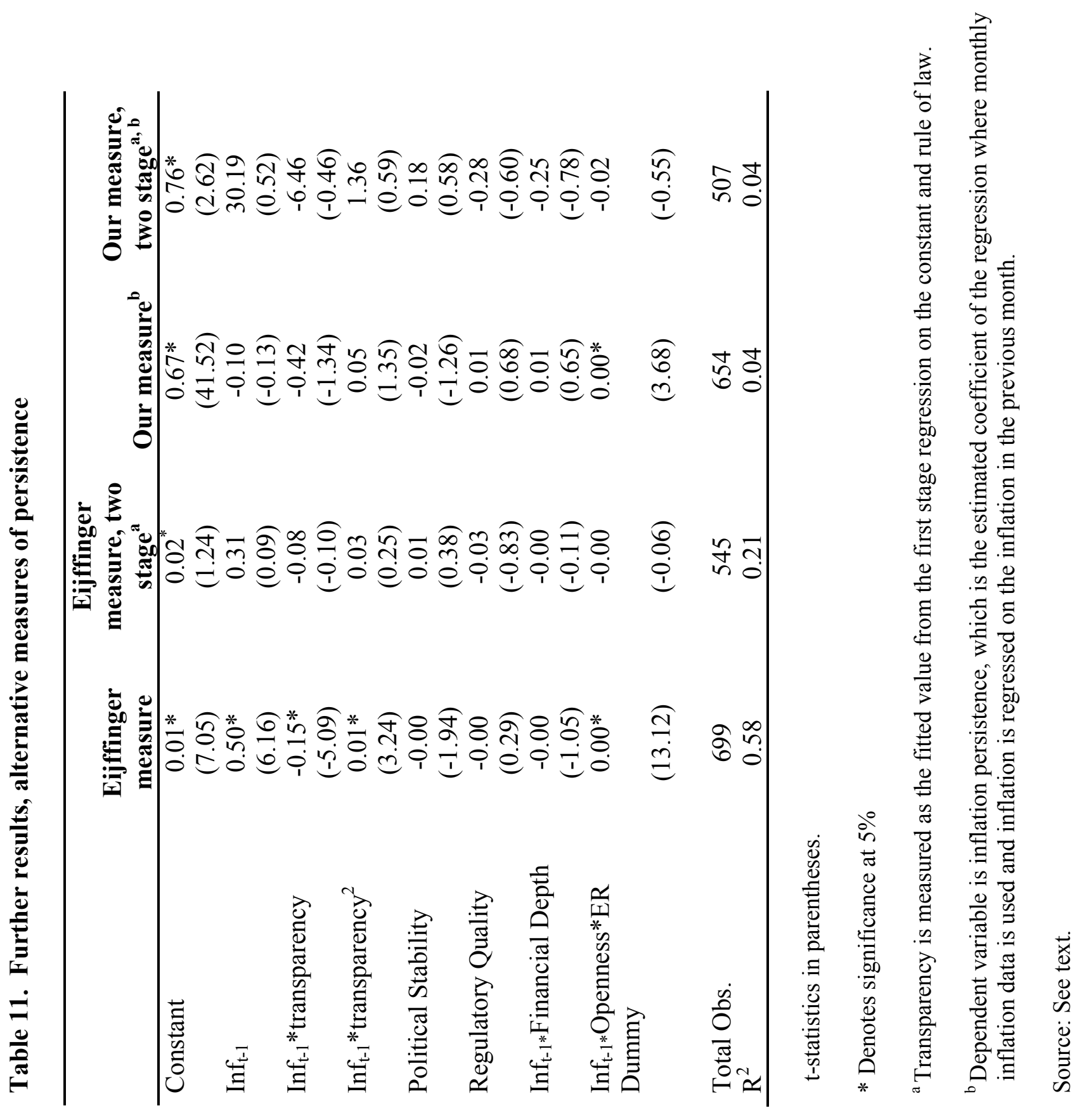


\section{Appendix A}

\section{Variable Definitions}

Definition of Inflation persistence: We take the 12 months of inflation data for the current year and regress inflation on inflation in the previous month. The estimated coefficient is the measure of inflation persistence in the regression equation.

\section{Source for Political Indicators data and detailed country ratings:}

'Governance Matters VII: Aggregate and Individual Governance Indicators for 1996-2007', by D. Kaufmann, A.Kraay and M. Mastruzzi, www.worldbank.org/wbi/governance

1. Voice and Accountability (VA) - measuring perceptions of the extent to which a country's citizens are able to participate in selecting their government, as well as freedom of expression, freedom of association, and a free media.

2. Political Stability and Absence of Violence $(P V)$ - measuring perceptions of the likelihood that the government will be destabilized or overthrown by unconstitutional or violent means, including politically-motivated violence and terrorism.

3. Government Effectiveness (GE) - measuring perceptions of the quality of public services, the quality of the civil service and the degree of its independence from political pressures, the quality of policy formulation and implementation, and the credibility of the government's commitment to such policies.

4. Regulatory Quality $(R Q)$ - measuring perceptions of the ability of the government to formulate and implement sound policies and regulations that permit and promote private sector development.

5. Rule of Law $(R L)$ - measuring perceptions of the extent to which agents have confidence in and abide by the rules of society, and in particular the quality of contract enforcement, property rights, the police, and the courts, as well as the likelihood of crime and violence. 

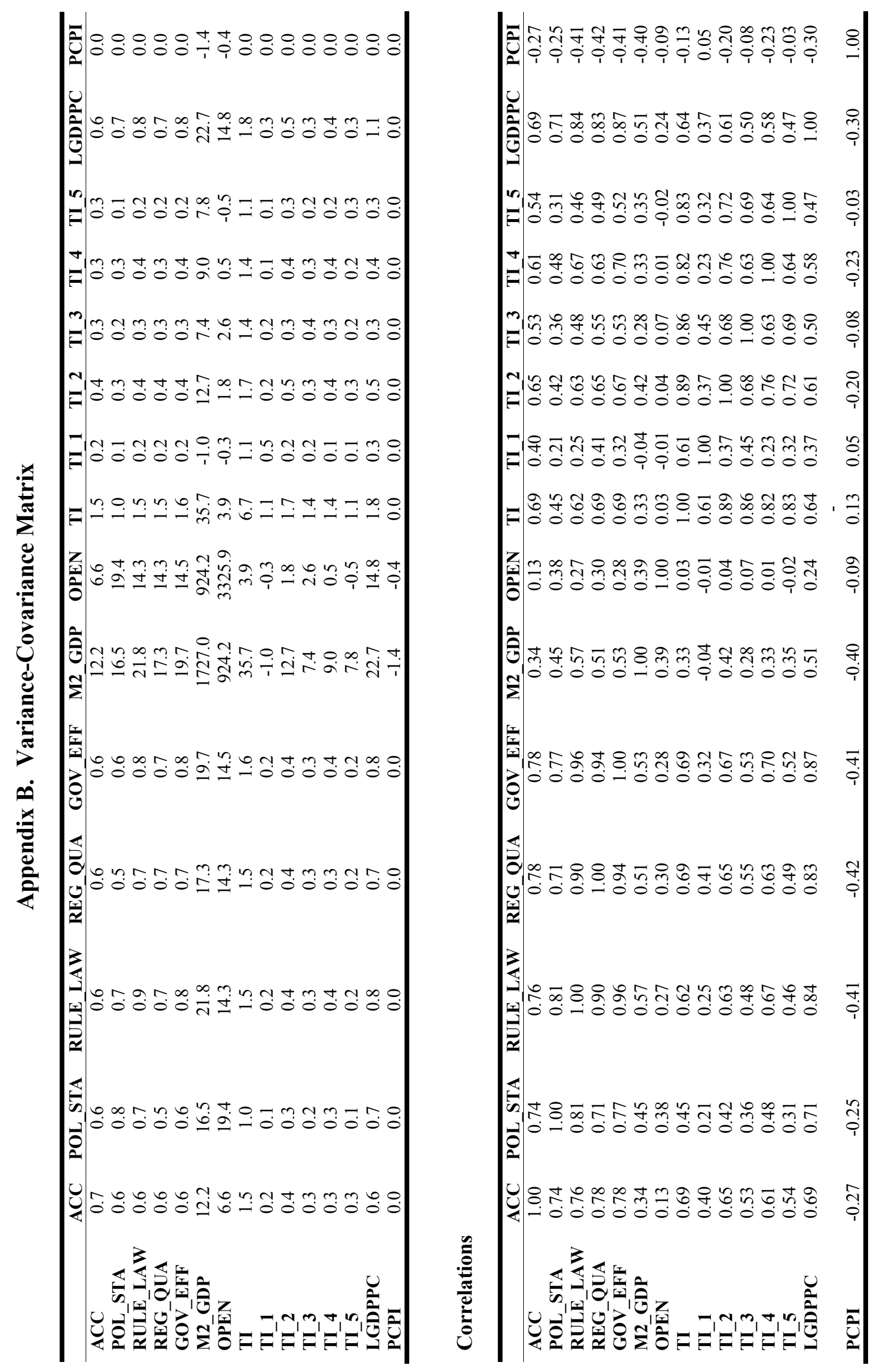


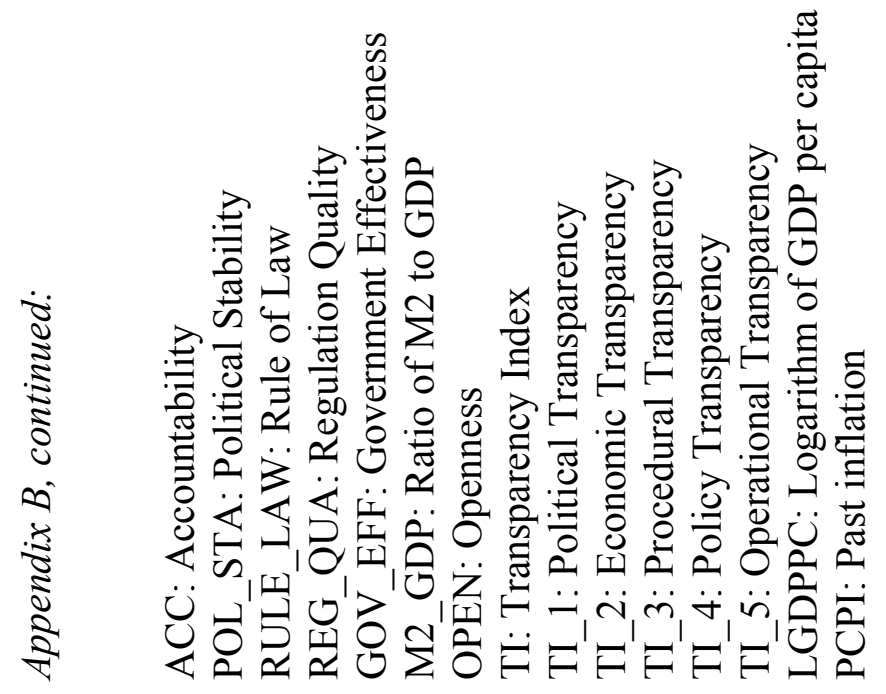




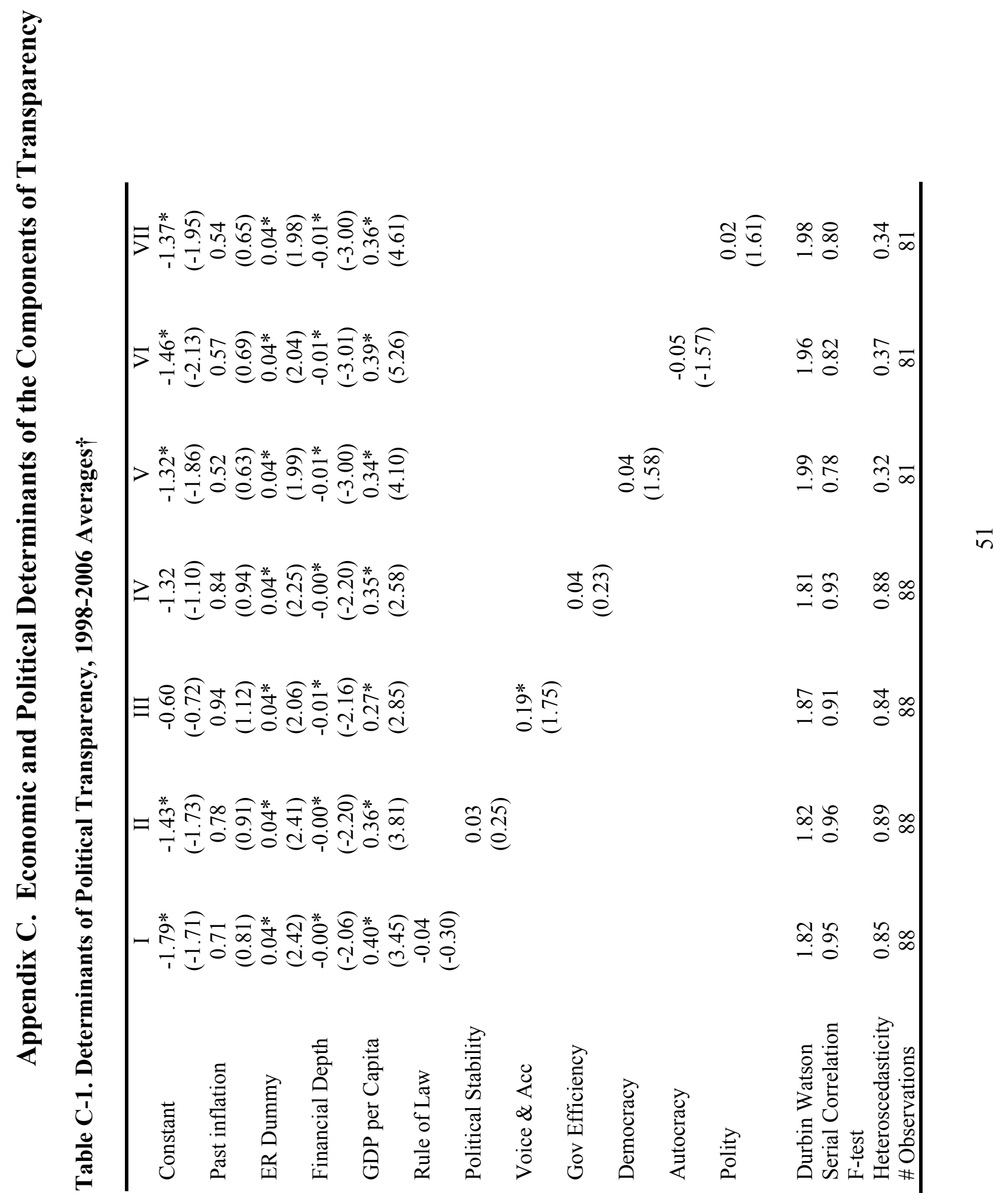




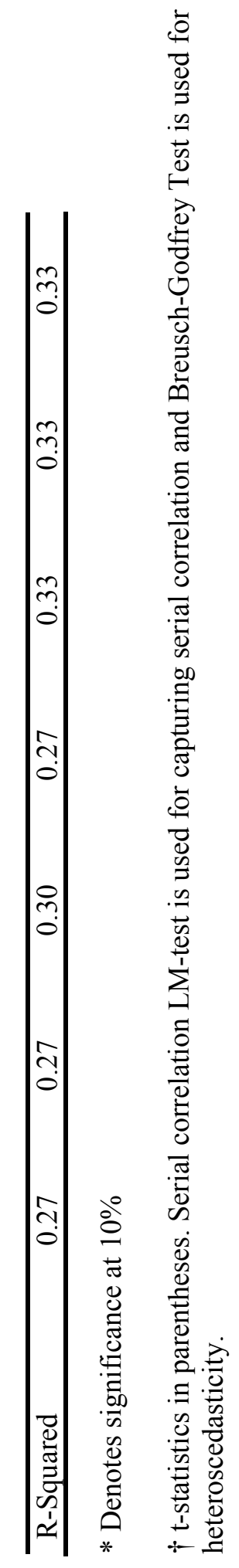




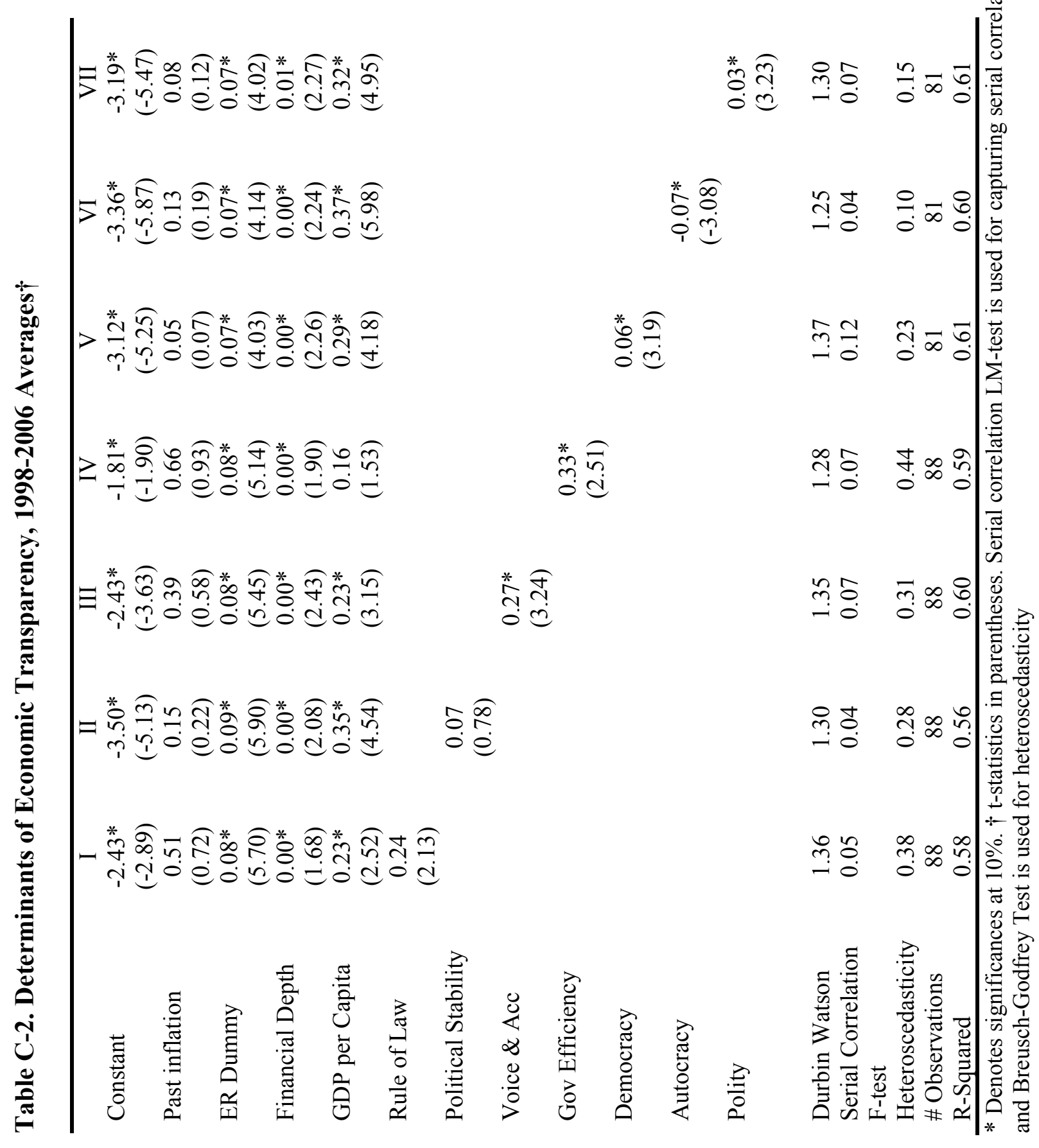




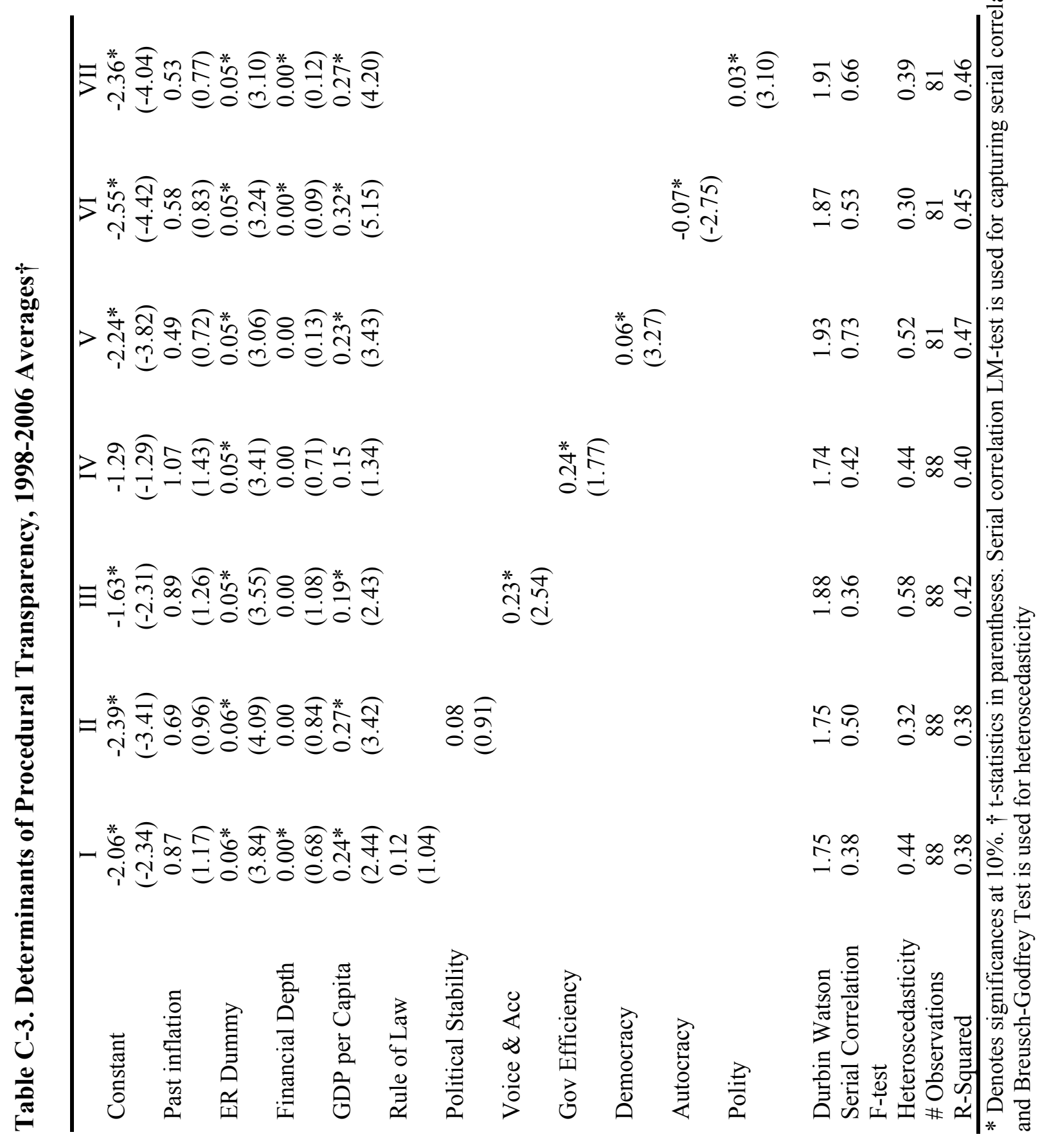




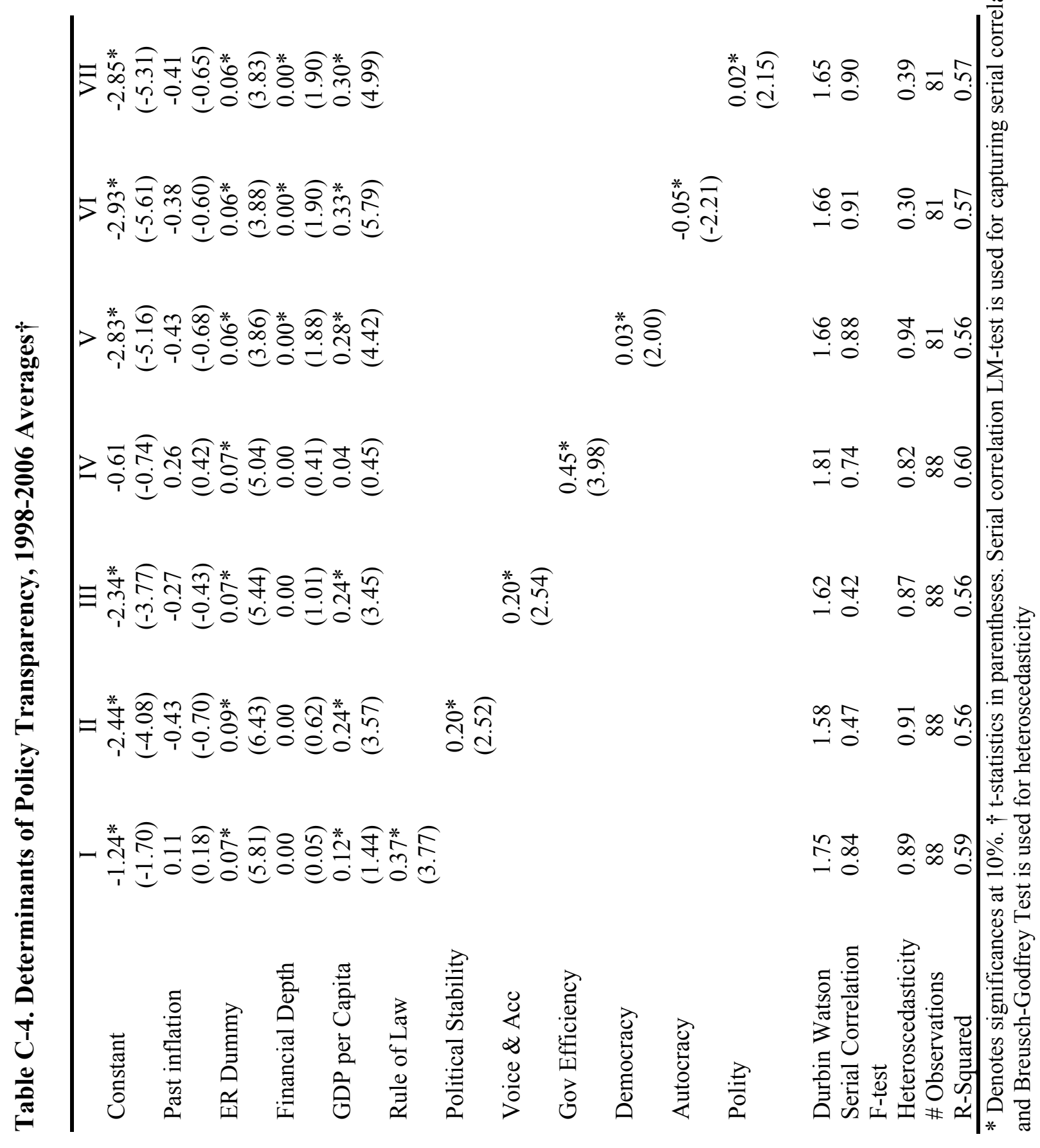




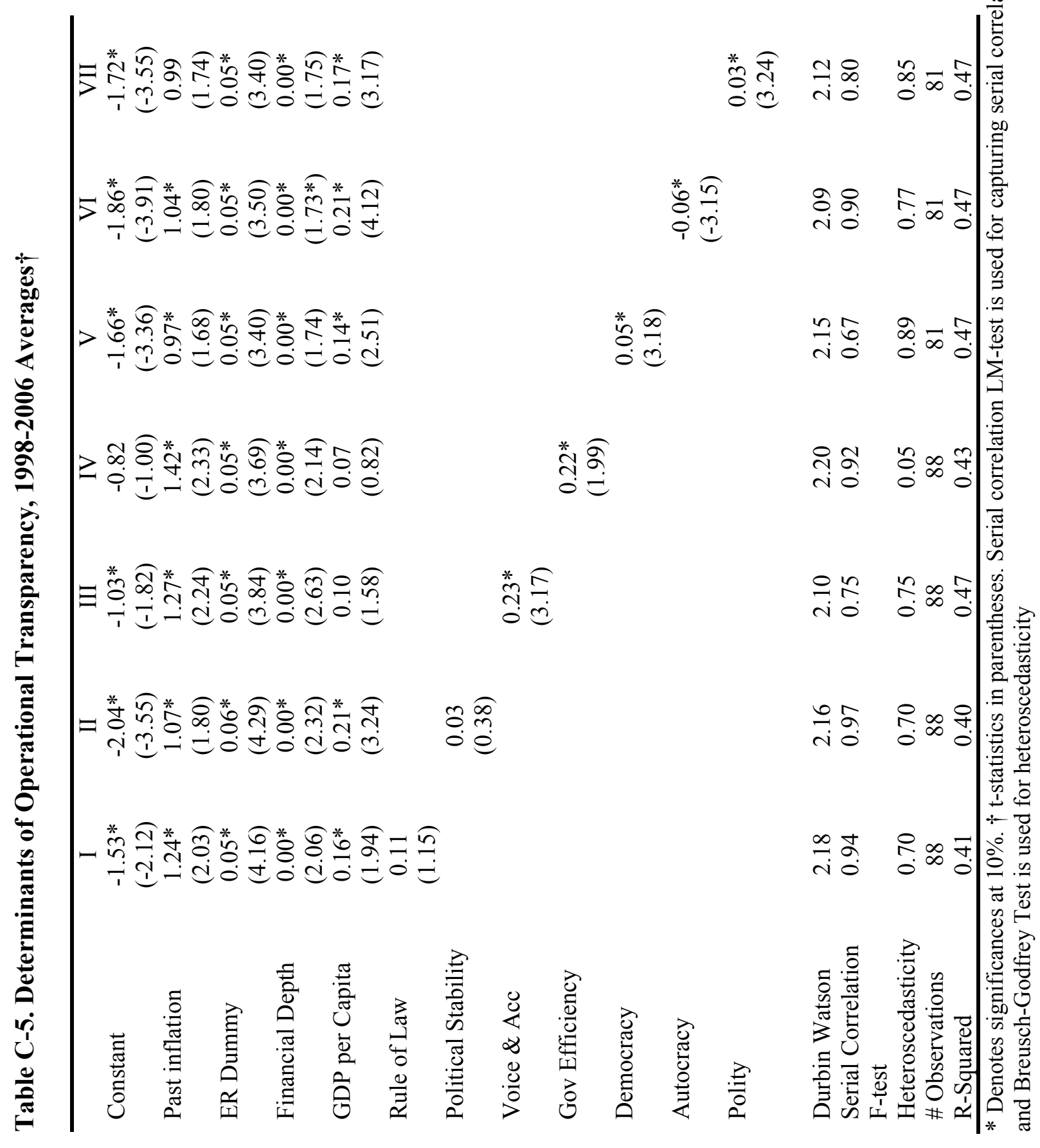




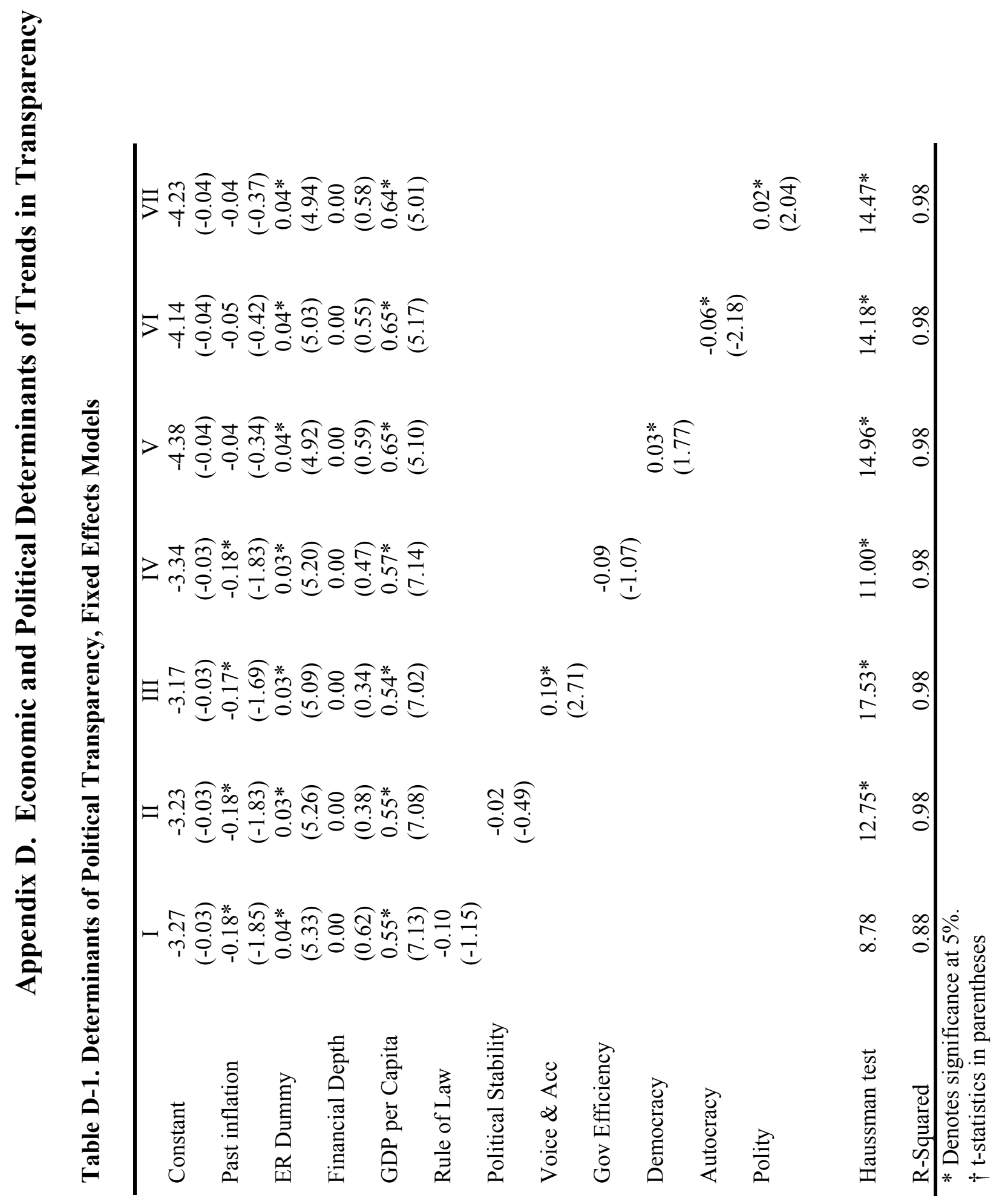




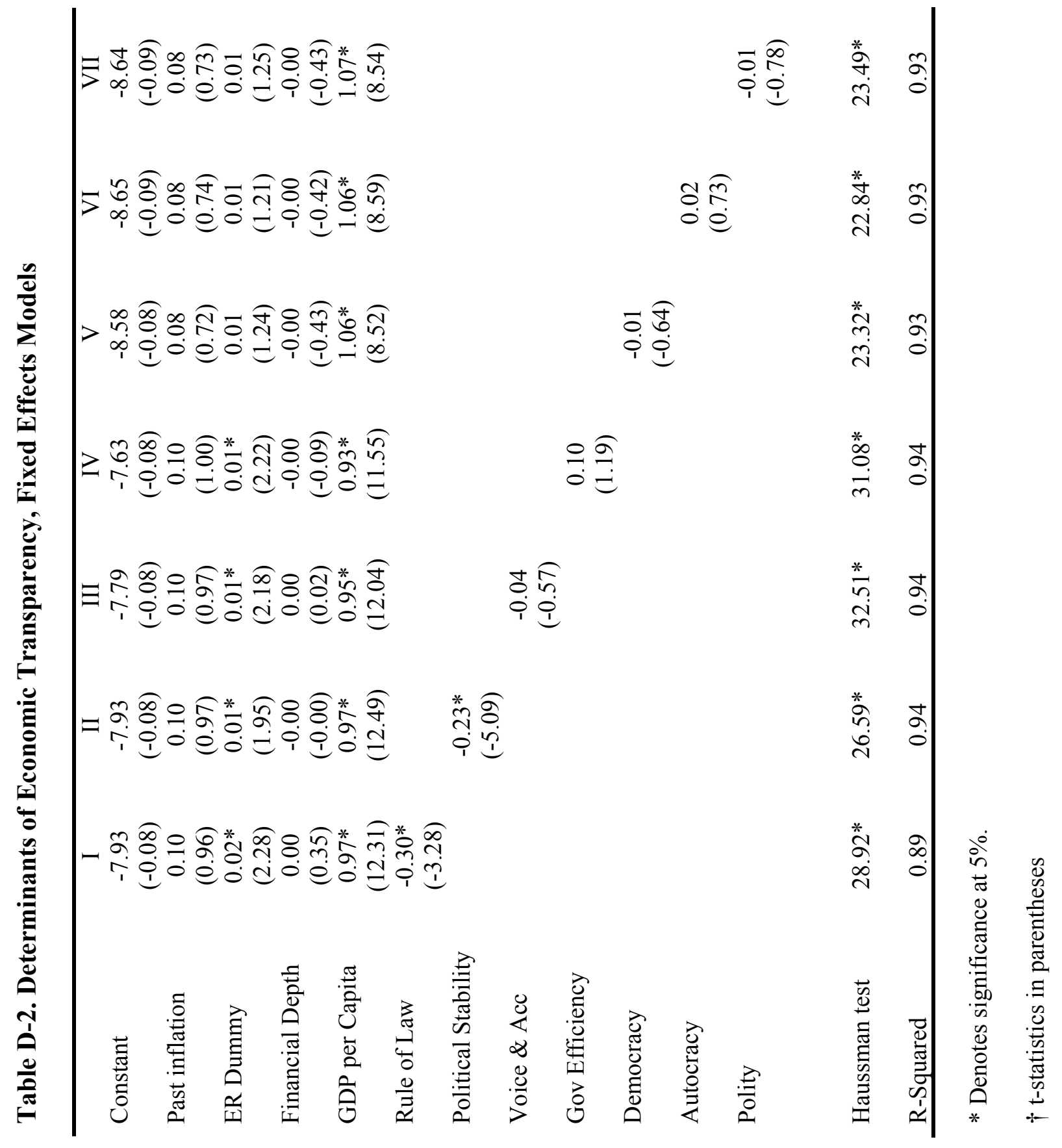




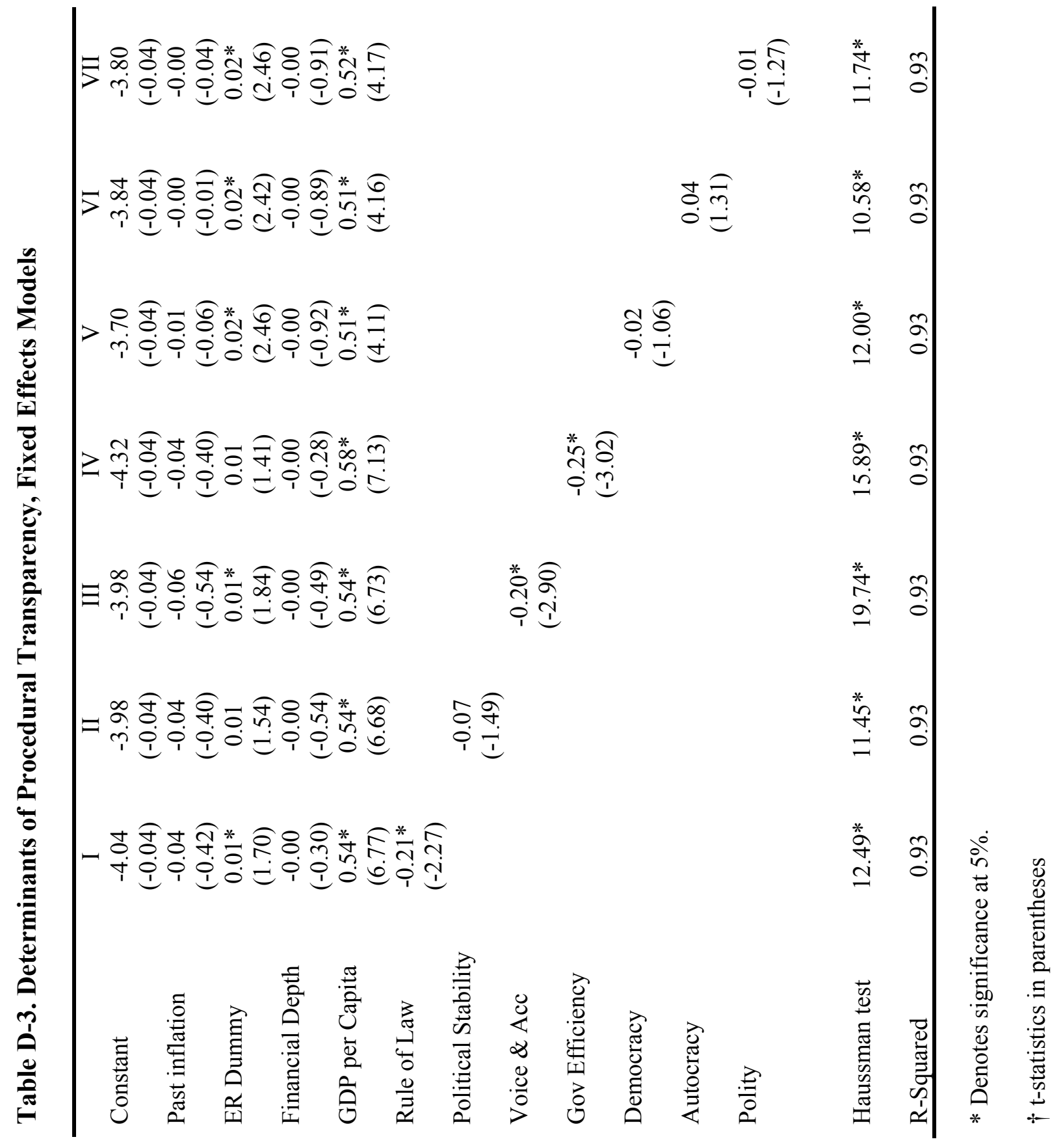




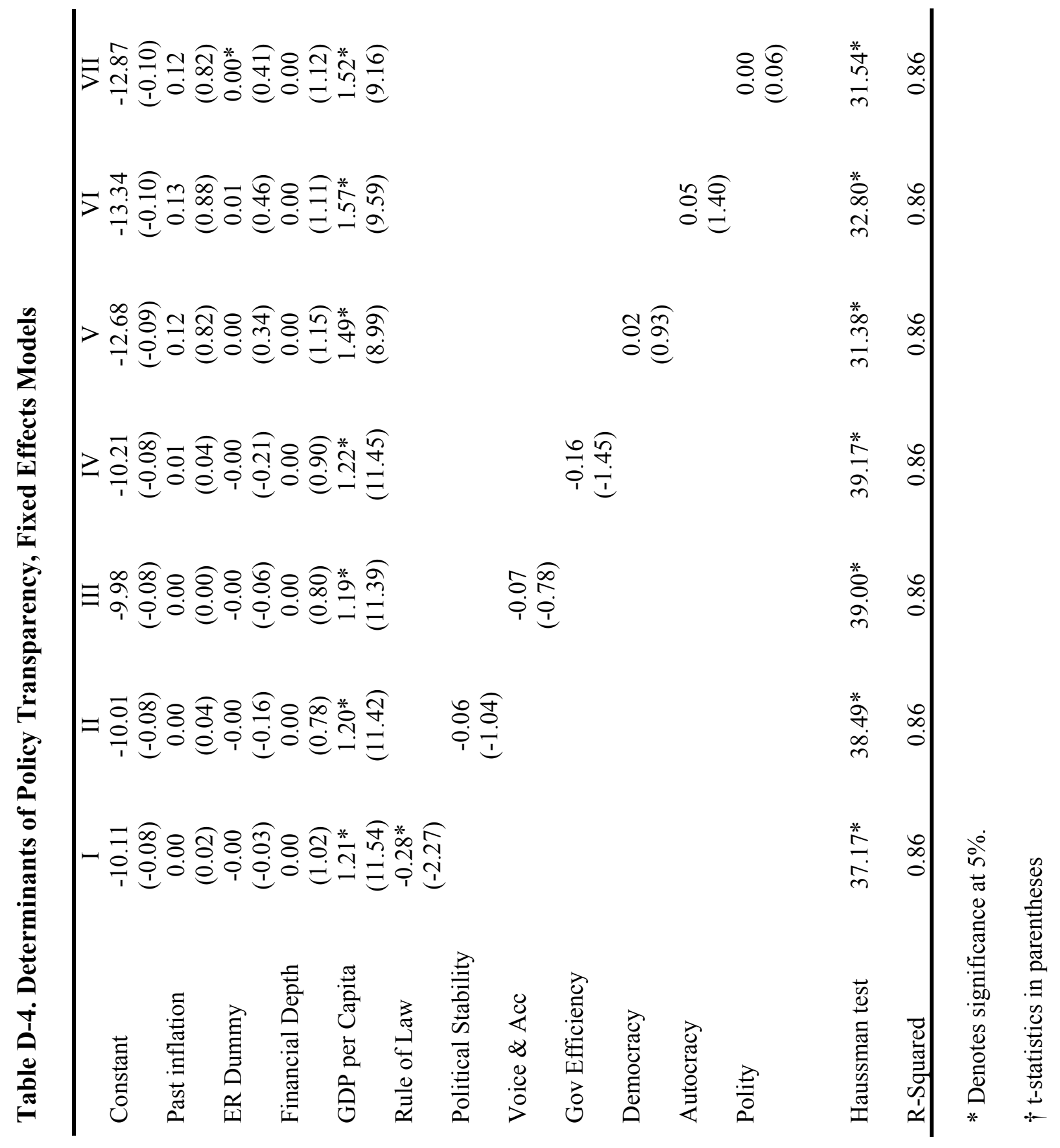




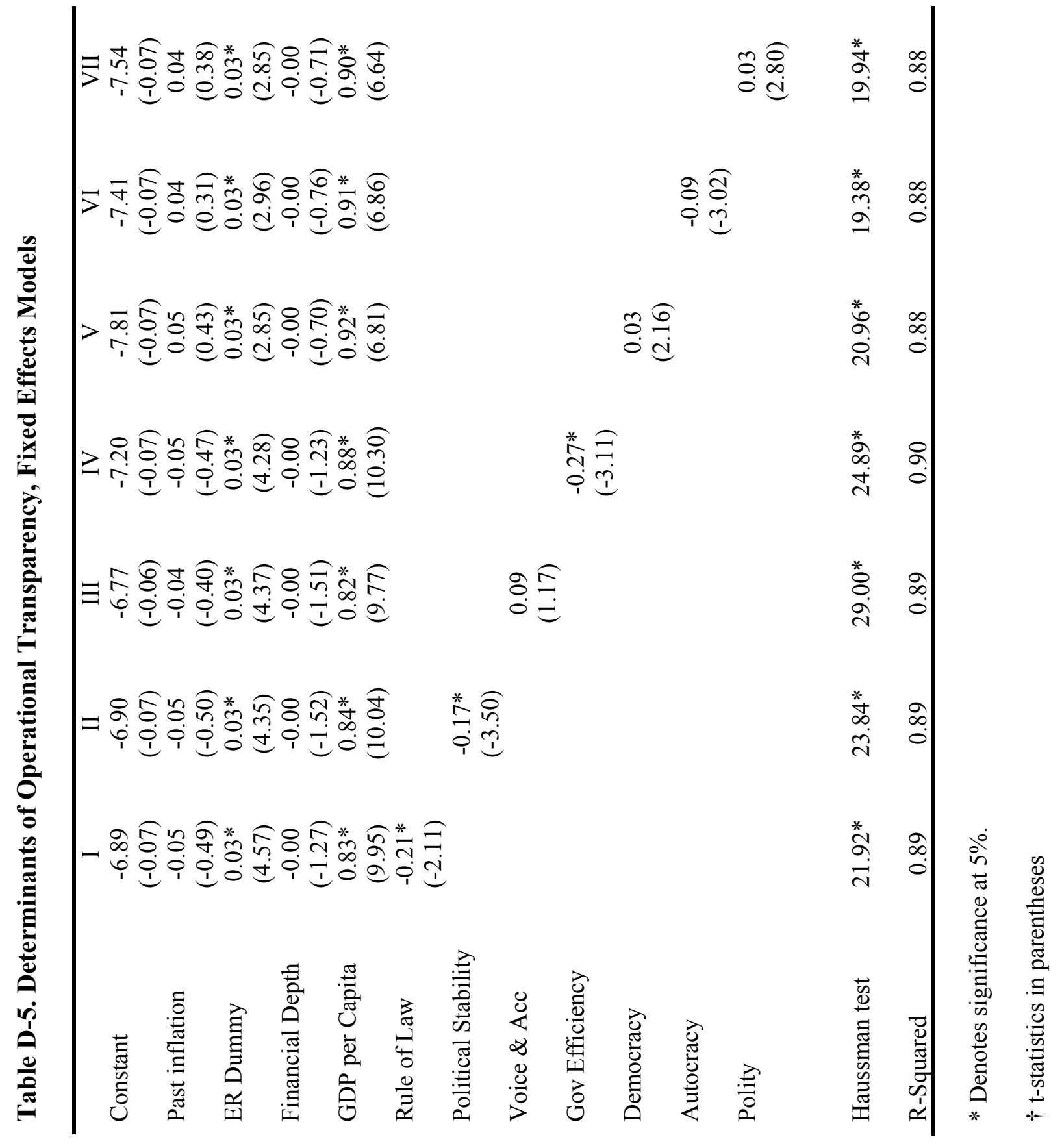


